\title{
To Test or Not? Singular or Multiple Heritage?
}

\section{Citation}

Hochschild, Jennifer L., and Maya Sen. 2015. “To Test or Not? Singular or Multiple Heritage?" Du Bois Rev. 12 (02): 321-347. doi:10.1017/s1742058x15000168.

\section{Published Version}

doi:10.1017/S1742058X15000168

\section{Permanent link}

http://nrs.harvard.edu/urn-3:HUL.InstRepos:27722614

\section{Terms of Use}

This article was downloaded from Harvard University's DASH repository, and is made available under the terms and conditions applicable to Open Access Policy Articles, as set forth at http:// nrs.harvard.edu/urn-3:HUL.InstRepos:dash.current.terms-of-use\#OAP

\section{Share Your Story}

The Harvard community has made this article openly available.

Please share how this access benefits you. Submit a story.

\section{Accessibility}


$\mid<$ SH>STATE OF THE ART

(

<AT>TO TEST OR NOT? SINGULAR OR MULTIPLE HERITAGE?

Genomic Ancestry Testing and Americans' Racial Identity

$<$ AU $>$ Jennifer L. Hochschild

$<A A>$ Department of African and African American Studies, Harvard University

$<$ AU $>$ Maya Sen

$<A A>$ John F. Kennedy School of Government, Harvard University

LRH: Jennifer L. Hochschild and Maya Sen

| RRH: Genomic Ancestry Testing

\section{$<\mathrm{AB}>$ Abstract}

DNA ancestry testing may seem frivolous, but it points to two crucial questions: First, what is the relationship, if any, between biology and race? Second, how much and why do people prefer clear, singular racial identities over blurred, mixed racial self-understandings, or the reverse? We posit that individuals of different racial or ethnic backgrounds will have different levels of support for this new technology._In particular, despite the history of harm caused by the biologization of race, we theorize that African Americans will be receptive to the use of DNA ancestry testing because conventional ge- 
nealogical searches for ancestral roots are mostly unavailable to them. This "broken chain" theory leads to two hypotheses, of disproportionately high Black interest in DNA ancestry testing = thus an implicit acceptance of a link between biology and race------and high acceptance among Blacks of multiple heritages despite a preference for evidence of roots in Africa.

To test these hypotheses, we analyze two databases of U.S. newspaper articles, one with almost 6,000 items and a second with 700 . We also analyze two new public opinion surveys of nationally representative samples of adult Americans. Most of the evidence comes from the second survey, which uses vignettes to obtain views about varied results of DNA ancestry testing. We find that the media increasingly report on the links between genetic inheritance and race, and emphasize singular racial ancestry more than multiple heritages. The surveys show, consistent with our theory, that Blacks (and Hispanics, to some degree) are especially receptive to DNA ancestry testing, and are pleased with not only a finding of group singularity but also a finding of multiple points of origin. Qualitative readings of media reports illuminate some of the reasons behind these survey findings. We conclude with a brief discussion of the broader importance of DNA ancestry testing.

$<$ KW>Keywords: Biology, Genetics, Ancestry, Racial Identity, Racial Definitions, Multiracialism, Public Opinion

There is no need for paper records to confirm this ancestral connection. It is there in your DNA.

—Brian Sykes, DNA USA: A Genetic Portrait of America (2012, p. 23 $)$ 
Oh no. Oh no. ... We got to have a re-vote. This ain't right.

- Snoop Dogg, on learning through DNA testing that he has four percent more European ancestry than Charles Barkley You Tube: "Lopez Tonight-Snoop Dogg's DNA Test"

\section{INTRODUCTION}

Viewed from one angle, DNA ancestry testing is a small, rather esoteric parlor game. Ei-

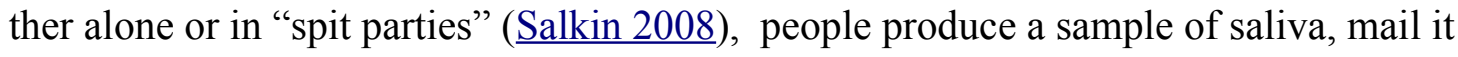
off, and a few weeks later open a website to discover the region of the world from which one ancestral line came or the proportion of their full ancestry from different continent-wide areas of the world. This technological novelty is intriguing, but it says nothing about the rich history of one's forebears or why they moved from (or remained at) their original location. As two scientists put it, "Genetics researchers are telling us that you are better off digging around in your loft than doing a DNA ancestry test if you want to find out about your family tree" (Collins 2013,-p._-). Or more simply, "This is business, and the business is genetic astrology" (Collins 2013). ${ }^{1}$

Viewed from another angle, however, and regardless of whether er not the science is any better than astrology, DNA ancestry testing raises profound questionsissues, potentially affecting everything from a person's identity to a society's strategy for categorizing racespurported racial groups. Two such questions-issues are whether and how to incorporate biological elements into the meaning of "race" or the distinctions among groups- and how to evaluate the relative merits of single-race ancestry and multiple group heritages.

We cannot finally adjudicate whether biology is implicated in race, or whether single-race or multiracial identity is preferable. No one can; these are matters of definition, ideology, and preference, not matters of fact. But we can add a new element to long-standing debates over biology and identity by analyzing how Americans 
understand and respond to DNA ancestry testing. Do citizens reject it, as coming too close to the old and discredited "racial science," or do they embrace it as a new tool for learning more about their own and others' heritage? Do Americans prefer to understand themselves through a clean, clear single group lineage or do they embrace the messy contingencies of multiracialism? Since both of these questions have been especially fraught throughout the long history of Blacks in America, we focus on the views of African Americans, comparing their views to the viewsthose of others in order to see what is distinctive and what is shared across groups.

We first briefly explicate the largest issues at stake and justify scholarly attention to DNA ancestry testing in that context. We then develop a theory that in turn leads to two hypotheses. The theory is based on the fact that many African Americans have suffered forcible breaks in their knowledge of their genealogical past, due to both the Middle Passage and the history and legacy of American slavery. For African Americans, the widely shared human desire to know where one came from seemed to be irretrievably frustrated - until DNA ancestry testing offered a possible way to gratify it. This "broken chain" theory leads to the firsttwo hypotheseis: $\underline{\text { First, }} \exists$ despite the dangers of biologizing race, Black Americans are interested in and receptive to DNA ancestry testing, perhaps more than other Americans are._It also leads the second hypothesis: $A$ Second, although African Americans may especially appreciate tests showing a single line of ancestry from Africa, they appreciate tests showing multiple ancestral lines as well,-, despite the painfulhistory of racial mixing in the United States. The logic here is that, since descendants of Ameriean African slaves hunger for any information about their genealogical ancestry, DNA tests that result in plural lineages are almost as gratifying as those that show a 
singular ancestry, despite the painful history of much racial mixing in the United States.

This view contrasts with that of racial and ethnic groups which that have not experienced the broken chain of genealogical knowledge; these groups have more psychological space to express preferences about the biological implications of DNA testing, and for learning about either a singular ancestral line or a multiple set of heritages.

We examine these two hypotheses in several steps. First, we look to a new General Social Survey (GSS) module which that suggests public, especially Black, receptivity to genomic science in general and to DNA ancestry testing in particulargiving initial credence to the first hypothesis. Second, we conduct a content analysis of almost 7000 newspaper articles to show the usefulness of the simple distinction between singular and multiple ancestral heritages — giving initial credence to the second hypothesis. This analysis also shows that Americans are more likely to receive the message that genomic testing reifies or strengthens racial boundaries than to receive the message that DNA testing blurs or dissolves them. Third, through an extended analysis of a vignette survey, we examine the two hypotheses about Blacks' distinctive interest in DNA ancestry testing and their attention to both a single ancestral line and multiple ancestries. Finally, we explore a subset of the newspaper articles in more qualitative detail in order to explicate the impulses and motivations behind the survey results. We conclude by discussing the implications of DNA ancestry testing for Blacks' fraught relationship with the view that racial identity is inherited, and for links between biology and race more generally.

\section{THE LARGE ISSUES BEHIND DNA ANCESTRY TESTING}




\section{Social Construction, Biology, and Race}

How should one understand the connection between the genetics of ancestry and racial identity? This is a new version of the old debate about whether distinctions among races and the concept of "race" itself are biologically based, purely human inventions, or some combination.

Although the idea has been extant at least since the nineteenth century, social constructivism now predominates among social scientists. The American Anthropological Association's (AAA) 1998 Statement on Race depicted it as “a worldview, a body of prejudgments that distorts our ideas about human differences and group behavior" (p. $\underline{713}$ ). The AAA insisted $\underline{\operatorname{argued}}$ that scholars should abjure its use (American Anthropological Association 1998). ${ }^{2}$ Many geneticists and medical researchers concur; as Luca Cavalli-Sforza and his co-authors put it in the pathbreaking History and Geography of Human Genes: "Classification into races has proved to be a futile exercise. . . The level at which we stop our classification is completely arbitrary. ... We can identify 'clusters' of populations ... [but] at no level can clusters be identified with races, since every level of clustering would determine a different partition and there is no biological reason to prefer a particular one" (Cavalli-Sforza et al. 1994), p. 19).-

Nevertheless, the historically stronger association between biology and race persists, in a new version. Researchers are exceedingly careful when they link race to genetic inheritance, but some nonetheless find it scientifically necessary to do so. One professor of medicine, for example, argues that "the debate ... should not be over the existence of population differences, but how to describe those differences with more 
precision ... . Railing against what some claim are misguided efforts to use racial, ethnic, or geographic distinctions does not make the differences disappear" (Cohn 2006), p. 553). Even Cavalli-Sforza and his co-authors provides color maps showing "very distinctly the [genetic] differences that we know exist among the continents: Africans (yellow), Caucasoids (green), Mongoloids, including American Indians (purple), and Australian Aborigines (red)" (Cavalli-Sforza et al. 1994, p. 136). ${ }^{3}$

Firms selling DNA tests straddle this divide; they state explicitly that results will not identify the user's race or ethnicity, but some of their language is more ambiguous. For example, geneticists Mark Shriver and Rick Kittles point to a "potential negative consequence" if data about ancestral categories are "misinterpreted as indications of 'real' racial divisions"- - but they also assert that a personalized genetic history "has the potential to affect ethnic, religious, racial, and family identities" (Shriver and Kittles 2008) 209). DNA Spectrum, an online seller of ancestry tests, advertises that its “propriety Full Spectrum Plus test [an autosomal DNA test—see below] has helped customers like James Shoemaker discover their true heritage" ( $\underline{P R W e b 2013}))$ Thus a person choosing to do a DNA ancestry test, or confronted with questions about her views of such a test, is implicitly participating in a long-standing discussion that can be as subtle and as sophisticated as Shriver and Kittles', or as blatant as eugenicists' claims about ethnic bloodlines.

\section{Singular and Multiple Ancestral Lineages}

The decision to take a DNA ancestry test leads to another decision, about which type of test to take. In very quick compass, one has two basic alternatives (although, unlike 
Robert Frost's traveler, one can take both roads ${ }^{4}$ since the tests are not empirically or analytically incompatible). ${ }^{5}$ Autosomal (non-sex-linked) tests seek to determine the proportions of a person's ancestry from different regions of the world. Such a test might show one hundred percent ancestry from one population group, but given human migration and marital patterns, it is likely to show descent from more than one region of the world. Mitochondrial and Y-DNA tests-(also known as mt-DNA tests), and Y-DNA

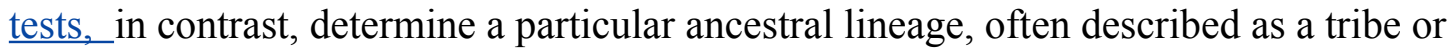
indigenous population, from the paternal line for men or maternal line for women. This test does not show population group mixtures since it provides information about one line of forebears.

Thus a person taking a DNA test necessarily participates in a second old debate, on the relative merits of attachment to a single group versus embrace of multiple ancestries or identities. Like willingness to grant legitimacy to DNA tests, this is a political and moral as well as personal and idiosyncratic choice. Endorsement of singular racial identity and clear boundaries between groups goes back at least to the racial nationalism of David Walker and Martin Delany, the inventors of blood quantum to determine Native American status, and (with a different political connotation) the White Citizens League. For Blacks, singular racial identity may be associated with commitment to the betterment of the group (Shelby 2005) and pride in one's previously denigrated heritage (Joseph 2007). The slogans "Black is beautiful" and "Black power" arose in thesame eraat roughly the same time, often among the same people, and usually conveying the same political message: "[F]rom now on we shall view ourselves as ... Black people who are in fact energetic, determined, intelligent, beautiful, and peace-loving" (Ture and 
Hamilton 1992), p. 38). ${ }^{6}$

Support for multiracial complexity and the blurring or dissolution of boundaries has different though equally robust historical roots: de Crèvecoeur's celebration of "the American, this new man"; Israel Zangwill's melting pot; and José Vasconcelos' raza cósmica. In the African American population, engagement with racial mixture has ranged from shame and outrage at slave owners" exploitation to pride in "good" hair and light skin color to endorsement of the right to celebrate the breadth of one's heritage, whatever it is. As Barack Obama put it, "I can no more disown [the Rev. Jeremiah Wright, Jr.] than I can disown my White grandmother"; he once observed that the kind of

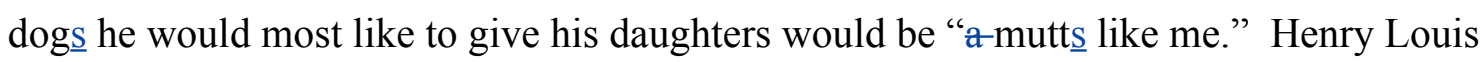
Gates, Jr. makes the same point, more exuberantly: Now that "we know [through DNA testing] that Jane Gates' children were fathered by an Irishman, I'm in pursuit of him 24 hours a day. He's my great-grandfather. I want nothing more than to find his identity and travel to Europe and claim his people for my own" (Morton 2012).

\section{THEORIZING RESPONSES TO DNA ANCESTRY TESTING}

\section{Biology and Race}

DNA ancestry testing draws one, willy nilly, into the issues of whether biology has any relationship to racial identity, and whether one should focus on a discrete, singular racial identity or on a heterogeneous mixture of group identities. Consider the first issue first. We know of no systematic theories, never mind a developed literature, on why people might endorse, accept, or resist the idea of an association between race and biology, so we provide the initial outline of such a theory and its links to DNA ancestry testing and 
African Americans below.

If a person believes it to be an indisputable fact that race is purely a social construction, he or she is likely to reject DNA ancestry testing as misleading. ${ }^{7}$ Similarly, if a person is a social constructivist out of ideological commitment or disgust at the uses to which purported racial science has been put, he or she is likely to reject DNA ancestry testing as dangerous. Conversely, a person who is willing to do a DNA ancestry test or who gives credence to its results can be assumed to accept the legitimacy of some sort of association between race and biology.

Given the uses to which racial science has been put, one might expect African Americans to reject any suggestion of such an association, and therefore to reject DNA ancestry testing. However, we theorize that Blacks might instead be drawn to DNA ancestry testing, perhaps even more than members of other groups are, and therefore willing to overcome any lingering fears of racial science. Our "broken chains" theory has two elements.

The first element is shared with other Americans - the profound urge to find one's roots. As Businessweek puts it, "today, genealogy ranks second only to porn as the most searched topic online" (Falconer 2012), p. 1. ABC Forbes Magazine reports that the genealogy industry is worth $\$ 1.6 \underline{2}$ billion dollars a year_(Anderson 2014), with the websites like Ancestry.com reporting over two million active userspaying subscribers as of 2012 (Farnham 2012). Groups vary in the geographic stability and therefore traceability of their ancestry, with American Blacks at the end of the continuum of difficulty. Unlike in other groups, the vast majority of Blacks whose ancestors came to America before the twentieth century are almost always unable to use conventional 
records to trace their antebellum ancestry. Slave ships counted but did not name their cargo. The United States census recorded only the number of slaves held by a (named) White owner through 1840, and only occasionally included (first) names in the 1850 and 1860 censuses. People changed their names or their names were changed regardless of their preferences. Few Blacks owned land or were on the tax rolls, many Black marriages and births were never officially recorded, few attended formal schools, and so onwritten records are scant and incomplete at best. So African Americans typically find popular genealogical sites such as Ancestry.com to be useless beyond a few generations.

The second element in the broken chains theory is distinctive, perhaps unique, to Black descendants of enslaved Africans. Finding one's ancestry can represent a type of victory over subjugation by Europeans:

For the first time since the seventeenth century, we are able, symbolically at least, to reverse the Middle Passage. Our ancestors brought something with them that not even the slave trade could take away: their own distinctive strands of DNA. . . . So an exact match between an American's DNA and an African's DNA reveals a shared ancestor, and possibly a shared ethnic identity, that has been lost for centuries (Gates Jr. 2008), p. 10).

Thus one woman cried for joy when discovering her Kenyan ancestry. "She carried a message from her ancestors in every cell ef her bedy [sic]; of her body, in her own DNA. It was a secret document, a talisman of her African roots. . . It had slid unseen past slave owners who had strived to erase any sense of individual identity from her ancestors (Sykes 2012), p. 135). By this logic, the deeper the erasure of history and family through enslavement, the more precious is the knowledge that can be gained only from DNA ancestry testing. "For 400 years, to have no clue as to your name, culture, heritage, where you came from- how could you not search? You need to find out who you are, just to get that fulfillment, even if it is just for a day, a second" (Ataiyero 2007). ${ }^{8}$ 
The broken chains theory generates our first hypothesis:

H1: African Americans are interested in, persuaded by, and influenced by DNA ancestry tests - and are more interested, persuaded, and influenced than are members of other American raciales and ethnic esties.groups.

\section{Singular or Multiple Heritage}

As with the issue of links between race and biology, the extensive literature on racial mixture has not produced a systematic theory about when or why people will prefer singular or plural group identities, or how that preference connects to DNA ancestry testing. So we begin with the broken chains theory, and develop it in a new direction in order to generate a testable hypothesis about views on racial mixture.

We expect two sets of people to be especially committed to a singular, or pure, group identity. The first set includes those whose social superiority depends in large part on belonging to a disproportionately favored group. Examples include Brahmins in the caste system of sub-continental India, the Cohanim among observant Jews, and Anglo-Saxon Whites through much of American history. The second set includes those reacting with anger and solidarity against the social inferiority predicated on belonging to a disproportionately disfavored group. Examples include homosexuals embracing the pejorative appellation of "gay" or "queer," the Roma across much of Europe, and Black Americans. In contrast to both sets, members of groups with mixed, mid-range, or highly variable social status are less likely to place a great deal of stock in singular or pure ancestry. 
Following this logic, we expect African Americans who are interested in DNA ancestry testing to be especially focused on and responsive to tests promising knowledge of singular African ancestry. This could either be an autosomal test that shows mostly African descent, or a mitochondrial or Y-DNA test that explicitly traces an African lineage.

A strong commitment to singular racial identity need not conflict, either logically or empirically, with acceptance of or enthusiasm about racial mixture. Analysts who embrace multiracialism argue that it permits a fluid racial identity, such that one's selfdefinition can vary with context or preferences. ${ }^{9}$ That perspective seems less plausible for those whose social superiority depends on racial purity than for those who resist social inferiority; the former will lose status if they admit to multiple heritages, while the latter may gain status, or at least not lose it. Thus African Americans who are interested in DNA ancestry testing can take pride in their African heritage without having to reject the possibility of non-African ancestors. Hence our second hypothesis, which emerges from an extension of the broken chains theory:

H2: African Americans are especially favorable toward tests that reveal a single ancestral line, and favor racial singularity more than do all other groups except White Americans. Unlike White Americans, however, African Americans are also favorable toward DNA ancestry tests that reveal multiple ancestral lines.

\section{METHODS AND RESULTS}

\section{Expanding Awareness}


If only a few Americans are aware of the revolution in genomic science, or of genetics more generally, DNA ancestry testing will be of little interest except to a handful of specialists. But that is not the case.

Three initial analyses show that public attention to biology and genetics is growing or reasonably high. The first uses published books. . A Google Books Ngram (Figure 1) shows the diffusion of the words "genetic," "DNA," "biological," "gene[s]," and "genomic" in books published between 1940 and 2008. ${ }^{10}$ As Figure 1 shows, the proportion of books with all of these terms, except the highly specialized "genomic," increased markedly over those seventy years.

\section{[Figure 1 Here]}

The second piece of evidence about public attention to biology and genetics uses newspapers rather than books; it focuses specifically on genomic science and race or ethnicity. We conducted an automated content analysis of what we believe to be all newspaper articles published in the United States on the topic of genomics and race or ethnicity through 2009. .1 We used the broadest available database, on the grounds that it would best show how the print media are reporting this topic. For the same reason, we retained duplicates; an article's appearance in more than one newspaper is directly relevant to the question of public attention to biology and genetics. We erred on the side of being over-inclusive in order not to bias our corpus of texts toward or against our expectation of increasing attention, or toward or against our second hypothesis on the $\underline{\text { singular or multiple framing of DNA ancestry. }}$

Specifically, we searched the database for texts using a genetics-related term ("DNA." "genetic," or "genomics") ${ }^{12}$ within the same sentence as a word associated with 
race, ethnicity, or heredity ("race," "racial," "ethnicity," "genealogy," "descendant," "ancestor," "race," "racial," "ancestor," or "lineage"). We added keywords to exclude articles clearly outside our inquiry, such as those on rape or murder forensics, genetic food modification, television schedules, and death notices. We avoided words that would slant the search toward any particular group (e.g. "Black," "White," "African," "Celtic"). The final search yielded 5580 newspaper articles from 1969 through 2009; their yearly frequency is shown in Figure 2.

[Figure 2 Here]

The curve in Figure 2 resembles that of Figure 1; the annual number of newspaper articles linking DNA and race rose from fewer than 50 in 1990 to as many as 500 by the late 2000s. The number of relevant articles peaks around 2006, coinciding with Gates' first public television documentary on prominent African Americans' use of genetic testing. Journalistic interest remained strong through 2009..$^{13}$

Perhaps the best way to determine if someone is paying attention to an issue is to ask him or her directly; that is our third measure of awareness of genetics. By that criterion, $13 \%$ of respondents to the 2010 GSS have heard "a great deal" about genetic testing, and an additional 66\% have heard "something" about it. ${ }^{14}$ Similarly, in 2007. $\underline{49 \%}$ of survey respondents claimed to have thought "a great deal" or "a small amount" about "issues to do with genes or genetics" over the previous few months (Virginia Commonwealth University Life Sciences Survey, November 2007). We have no way of knowing if these figures are accurate; they are best understood as an indicator that half (in 2007) or to four fifths (in 2010) of Americans think they should be paying attention to genetics. 


\section{Media Presentations of Singular and Multiple Heritage}

Given that Americans are learning about genetics - or at least books and newspapers are providing more information and Americans think that they should be learning about genetics - we can move to the more focused question of what they are learning. The database of 5580 newspaper articles provides a lens through which to view the initial stages of public learning about links between the new genomic science and the

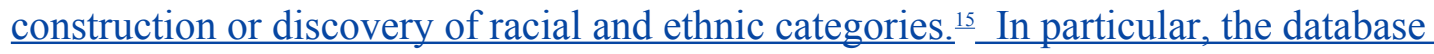
enables a determination of whether the distinction between group singularity and multiplicity, on which $\mathrm{H} 2$ is based, is publicly broadly meaningful.

We sorted the media reports of links between DNA ancestry tests and race or ethnicity into two bins: (1) those that emphasize multiplicity by focusing on group mixture or the softening of distinctions among conventionally defined races or ethnicities, and (2) those that emphasize singularity by focusing on reinforcement of one ancestral line or single-group identity, or on the hardening of distinctions among conventionally defined races or ethnicities (we also created two other bins for articles that do both, and articles that do neither). Since we could not code 5600 articles by hand, we used ReadMe (Hopkins and King 2010), an automated content analysis method for the R statistical computing language. Two research assistants and the authors hand coded over 600 articles selected across the full period, dividing them into four mutually exclusive categories. This was the "training set." We ran the content analysis program on the training set, thereby allowing the program to use the proportion of documents observed with each pattern of word profiles to make predictions. We then used the same 
classification method to analyze all 5580 articles (the "test set"). The program estimated the proportion of articles in each substantive category with good accuracy (Hopkins and King, 2010).

The four categories and the coder instructions were:

Blend [now called Plurality]: The article implied or stated that recent advances in genetics or DNA technology blend racial or ethnic identity or identification. Articles that imply shared ancestry fall in this category.

Strengthen [now called Singularity]: The article suggested that recent advances in genetics or DNA technology could reify, strengthen, or focus racial or ethnic identity or classification by others.

Both: The article stated or implied that advances in genetics or DNA technology can both blend and strengthen racial identity or classification by others. Or it discusses different people, some of whom move in the direction of blending and others in the direction of strengthening racial identity.

Neither: The article did not mention these issues, or expressed or implied no view on whether advancements in genetics blend or reinforce racial identity.

For example, a description of recent research that included analysis of a newly discovered gene shared among humans from all regions of the world would be coded as "Blend," since it conveys the idea that DNA points to a shared human origin. In contrast, an article discussing the relatively high prevalence of breast cancer among Jewish women and speculating that genetic factors unique to Jews are linked to the increased risk would be coded as "Strengthen," since it implies that genomic science reveals biological distinctions among racial or ethnic groups.

[Table 1 Here]

Table 1 shows the estimated proportion of articles in each category, as generated by the automated content analysis. About three tenths of the articles framed DNA ancestry testing in terms of singular racial identifications, while a fifth focused on 
multiplicity across racial groups. Another tenth addressed both concepts. ${ }^{16}-$

Methodologically, these results show that the dichotomous framework of plurality and singularity is meaningful and useful. We can effectively hand-code, and then automatically code, articles according to this distinction, and the coding yields interpretable and internally consistent patterns. Substantively, the results show that since genomics research has come into public view, both singularity and plurality of heritages have been included in public discourse. However, Americans have been more exposed to the idea that genomic science distinguishes races genetically or that people "belong" to only one group than to the idea that genomic science erodes group boundaries or shows people to have mixed biogeographical origins. This emphasis on racial singularity could have political impact_- but whether it reifies harmful and artificial barriers between groups or encourages solidarity and group pride remains to be seen.

Figure 3 provides a more dynamic portrait of what newspapers are conveying to Americans about genomics and race. It shows the proportion of articles in each of the three substantive coding categories separately by year from 1988 through 2009. (For ease of interpretation, we removed the fourth category, "Neither," from the denominator in calculating these proportions.)

\section{[Figure 3 Here]}

The proportion of articles discussing both multiplicity and singularity (the dashed line) is consistent but low. More interestingly, after the instability due to a small number of articles in the early 1990s settles down, in almost every year the articles focus as much or more on a single racial group (dark line) as on mixture or multiple groups (dotted line). The first exception is 2001 , which is probably due to publicity about the new mixed-race 
option on the U.S. census, and the public unveiling of the Human Genome Project. J. Craig Venter's statement in his White House speech that geneticists have shown that "the concept of race has no genetic or scientific basis" (Venter 2007).p. 315) was widely noted in that year, but Figure 3 shows that its message did not last in the media. The only other exception to the dominant message about racial singularity is 2009 , which is probably due to publicity about President Obama's racially mixed ancestry. ${ }^{17}$ -

\section{H1: Views of DNA Ancestry Testing}

The Ngrams, newspaper content analysis, and survey results show that the media are providing Americans with information about genetics and the links between genetics and race. They also show that a considerable portion of Americans is aware of this new endeavor. The distinction between singular and multiple ancestries in newspaper stories reveals a meaningful structure represents a meaningful difference in how information is conveyed.,in ongoing public discussions about genomics and race or ethnicity. at least among articles discussing both DNA and groups. That set of findings provides a sufficient empirical foundation to enable us to turn directly to the hypotheses. We focus first on H1: African Americans are interested in, persuaded by, and influenced by DNA ancestry tests-and are more interested, persuaded, and influenced than are members of other American races and ethnicities.

Initial support for H1 comes from our 2010 GSS module. So far as we can tell, this is the first nationally representative survey to ask views on "the use of DNA in order to research one's ancestry." According to the survey, $63 \%$ of the respondents were "strongly" or "somewhat" favorable to the use of DNA for these purposesthis purpose 
and only $9 \%$ were unfavorable. Blacks were more likely than Whites and Hispanics to be "strongly" favorable (proportions were $42 \%, 29 \%$, and $39 \%$, respectively), as well as more likely to "somewhat" favor it. Overall, three fourths of Blacks, compared with just over three fifths of Whites and Hispanics, approved of DNA ancestry testing. The GSS result is clear, but thin. For a clearer understanding of just what people approve and why, we turn to Our main evidence, however, is a new vignette survey, first reported here. It included a random sample of 1095 American adults, divided among 242 non-Hispanic Whites, 201 non-Hispanic Blacks, 233 non-Hispanic Asian Americans, 205 Hispanics, and 214 non-Hispanic multiracials..${ }^{18}$ All respondents identified their own race or ethnicity. The survey was conducted over the Internet by Knowledge Networks (now part of GfK) in August 2010, through the peer-reviewed Time-sharing Experiments for $\underline{\text { the Social Sciences (TESS) program. }}$

In order to examine difficult concepts with which few people have direct experience, we developed vignettes (Finch 1987) featuring imaginary people who have just received the results of a DNA ancestry test. Each participant responded to four vignettes. The respondent's gender always matched that of the imagined subject. Two vignettes (one each for racial plurality and racial singularity) asked the respondent to imagine that he or she was the vignette individual; in these cases, the respondent's pretest race (including Hispanic as a separate category) matched the pre-test race of each imaginary subject. The other two vignettes (again, one each for racial plurality and racial singularity), asked the respondent to imagine how the vignette individual would feel after receiving test results. Here the respondent's pre-test race differed randomly from the pretest race of each imaginary subject. 
These variations allow for an analysis of the internal validity of responses to the vignettes. That is, given the United States' fraught racial history, we anticipate that meaningful answers will vary in intelligible ways depending on whether the respondent is considering a vignette subject with the same or a different race from his or her own. Furthermore, people may consider their own experiences differently than they think about the experiences of others. For example, a Black respondent might convey more enthusiasm when asked to identify with a Black vignette character than when asked to assess the likely level of enthusiasm held by someone of a different race.

Each vignette had the same three sets of response categories, addressing: (1) emotional reactions to the ancestry test on a seven-point scale from "pleased" to "displeased"; (2) cognitive responses on a seven-point scale from "believable" to "unbelievable"; and (3) the test's impact with two alternatives, "would the results matter a lot to your identity" or ". . . not matter at all to your identity." 19 For each vignette, the screen showed a map of the world with the relevant continent(s) highlighted, as in Figure 4.

[Figure 4 Here]

Table 2 provides examples of how the vignettes Table 3 presents results for the emotional response of "pleased," after collapsing the first three points on the seven-point scale. ${ }^{21} \mathrm{H} 1$, which posits that Blacks are especially favorable to DNA ancestry testing, receives strong support. The simplest measure makes the point most clearly. Averaging across the four vignettes, $51.5 \%$ of both Blacks and Hispanics would be pleased with either result or would expect others to be pleased with either result. This compares with $43.8 \%$ of multiracials, and only $38 \%$ of Asians and $37 \%$ 


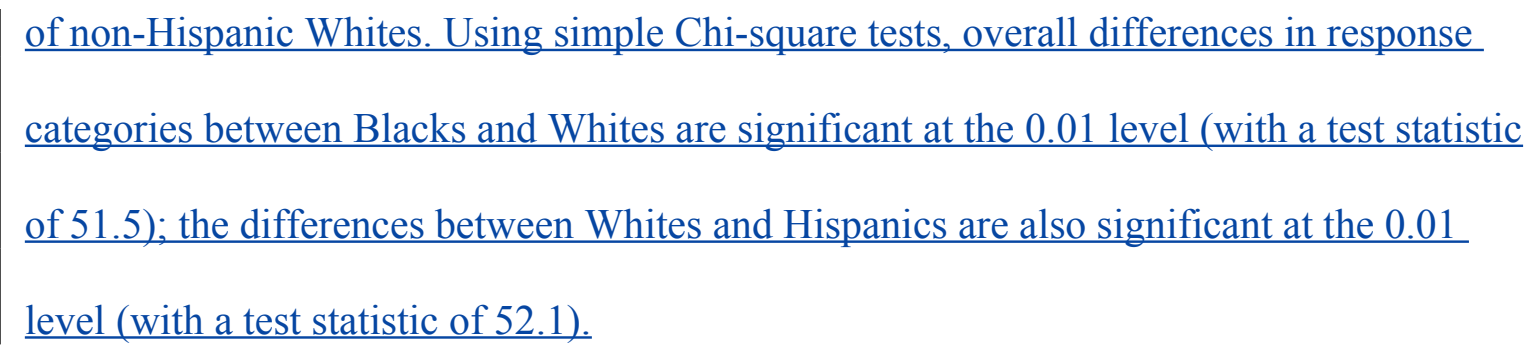

Dividing the results in Table 3 between vignettes that present the respondents' views of how they would feel about a DNA ancestry test (row 1) and those that present respondents' expectation of how others (from a randomly selected group) might feel (row 2) provides a bit of nuance while reinforcing $\mathrm{H} 1$. With regard to their own view, averaging across the two conditions of singular and plural test results, a higher proportion of Blacks- $53 \%$ - express pleasure than is the case in any other group. Hispanics are close behind, at 49\%, but the proportions decline to a third among Whites.

For the question prompts looking only at the blurring multiple-ancestry narrative, the differences between Blacks and Whites, and Hispanics and Whites, are all significant at conventional levels of statistical significance, as determined by a series of weighted Chi-squared tests. For the White-Black comparison under the blurring multiple prompt, the weighted Chi-square statistic was 8.06 ( $p$-value 0.018 ) and the White-Latino comparable Chi-square statistic was 8.60 ( $p$-value 0.013 ). For the question prompts looking only at the strengthening singular-ancestry narrative, the differences between Whites and Blacks, and between Whites and Hispanics, are only narrowly nonsignificant. With regard to expectations of others' reactions, a slightly smaller proportion of 
Blacks, and slightly more than half of Latinos ( $50 \%$ and $54 \%$, respectively), anticipate that others would feel as they do. Some African Americans, that is, perceive their own group's exceptionalism. ${ }^{22}$ The share of multiracials, Whites, and Asians who anticipate others' pleasure with DNA ancestry test results range downward to $38 \%$ among Asian Americans. However, these differences are not significant at the standard levels.

$\underline{\text { Some Blacks are indifferent to the results posited in the four vignettes, but only an }}$ average of $11 \%$ would be displeased with the outcomes of the enterprise (that is the same or marginally fewer than in any other group; results not shown.. ${ }^{23}$ A majority of African Americans surveyed, in sum, do not harbor mistrust toward DNA ancestry testinginstead, they hold positive views of it. They are not associating DNA ancestry testing with the old and dangerous tropes of eugenics or racial science; it seems reasonable to infer that they perceive it to be a way of restoring the links in the broken chain of genealogy.

We turn next to the second set of responses to the vignettes, asking whether respondents would meet DNA test results with skepticism or acceptance. The results do not contradict H1 but they support it only marginally (data not shown). There is no substantial difference across the groups in agreement on whether the DNA test results would be believable if the respondent were the person in the vignette: ${ }_{2}^{24}$ the average proportion saying "yes" varies only from $59.5 \%$ for Asian Americans to $62.5 \%$ for multiracials and Blacks. On the vignettes about whether a target person of another race would find the test results believable, the proportion saying yes ranges from $58 \%$ for multiracials to $64.5 \%$ for Whites; Blacks are in the middle, at $61.5 \%$ saying yes. At the other end of the scale, Blacks and multiracials are less likely to say that the results are not 
believable than are the other three groups (14\% and 13\% for Blacks and multiracials, respectively, and $17 \%$ to $19 \%$ for the other three groups). Nonetheless, a series of Chisquare tests show no meaningful differences between Blacks and Whites, Hispanics and Whites, and also across all of the groups in levels of belief. In sum, a solid majority of respondents in all groups trust the outcome of a hypothetical DNA ancestry test-a result reassuring in terms of external validity of the survey but not strongly supportive of H1 about Black exceptionalism..$\underline{-25}$

We turn finally to the third set of responses to the vignette, which queried respondents' views about the impact of the DNA ancestry test result on their selfunderstanding or self-definitionidentity. Our goal for this item was to operationalize the rather abstract question of whether Americans see race or ethnicity is as purely a social construction in the mind of the American public or whether, in their view, it has a meaningful biological or "factual" component. Since this is the most cognitively difficult item, we offered only two stark choices rather than a 7-point range: would the test results "matter a lot/not matter at all to your [or to his/her] identity?" Table 4 shows the results.

\section{[Table 4 Here]}

The results support H1. Averaging across the four vignettes asked of each

respondent, $45 \%$ of African Americans agree with the strong statement that the test results would "matter a lot" to identity. That compares with $41.5 \%$ of Latinos, $36.5 \%$ of Asian Americans, $32.5 \%$ of multiracials, and only $24.25 \%$ of Whites. These differences are highly statistically significant. For example, for the blur multiplicity prompt asking respondents to identify with the vignette character, the differences between Blacks and Whites (Chi-square statistic $=18.9, p$-value $=0.00)$. Hispanics and Whites (Chi-square 
statistic $=12.7, p$-value $=0.00)$, and across all of the groups $($ Chi-square $=28.9, p$-value 0.00) are significant at conventional levels. The desire not to be associated with the old racial science probably leads some Whites to deny that genetic inheritance affects identity -but social desirability seems unlikely to explain why almost twice as many Blacks as Whites agree that knowing one's genetic heritage would strongly affect one's selfdefinitionunderstanding. Other responses to this survey have reassured us about its external validity, so the relatively and absolutely high level of Black agreement that DNA tests matter to identity seems worth taking seriously.

As before, looking at rows 1 and 2 separately helps to refine the general finding of support for H1 that we have seen so far in Figure 4. Members of all groups except African Americans are more likely to claim that DNA test results would matter to other people than to admit that they would matter to themselves. Put the other way around, Blacks are the only group among the five to agree that they would be as much influenced by ancestry tests as they would expect others to be. The consistency of this pattern is reassuring from the perspective of internal validity, since it implies that respondents were meaningfully distinguishing between projecting themselves into the vignette and predicting how others might react. Why both White and non-White Americans (except Blacks) think DNA ancestry tests will matter to others but not themselves remains one of the many topics for further exploration that this research has opened up. The central point is clear, however: As our theory proposed, DNA ancestry tests are especially if not uniquely meaningful to Black Americans, many of whom want to find links that can repair the broken chains caused by the Middle Passage and enslavement. 


\section{H2: Singular and Multiple Ancestries}

Given evidence of blacks' unusually strong interest in DNA ancestry testing, we can turn to H2: African Americans are especially favorable toward tests that reveal a single ancestral line, and are more favorable to racial singularity than are all other groups except White Americans. Unlike White Americans, however, African Americans are also favorable toward DNA ancestry tests that reveal multiple ancestral lines.

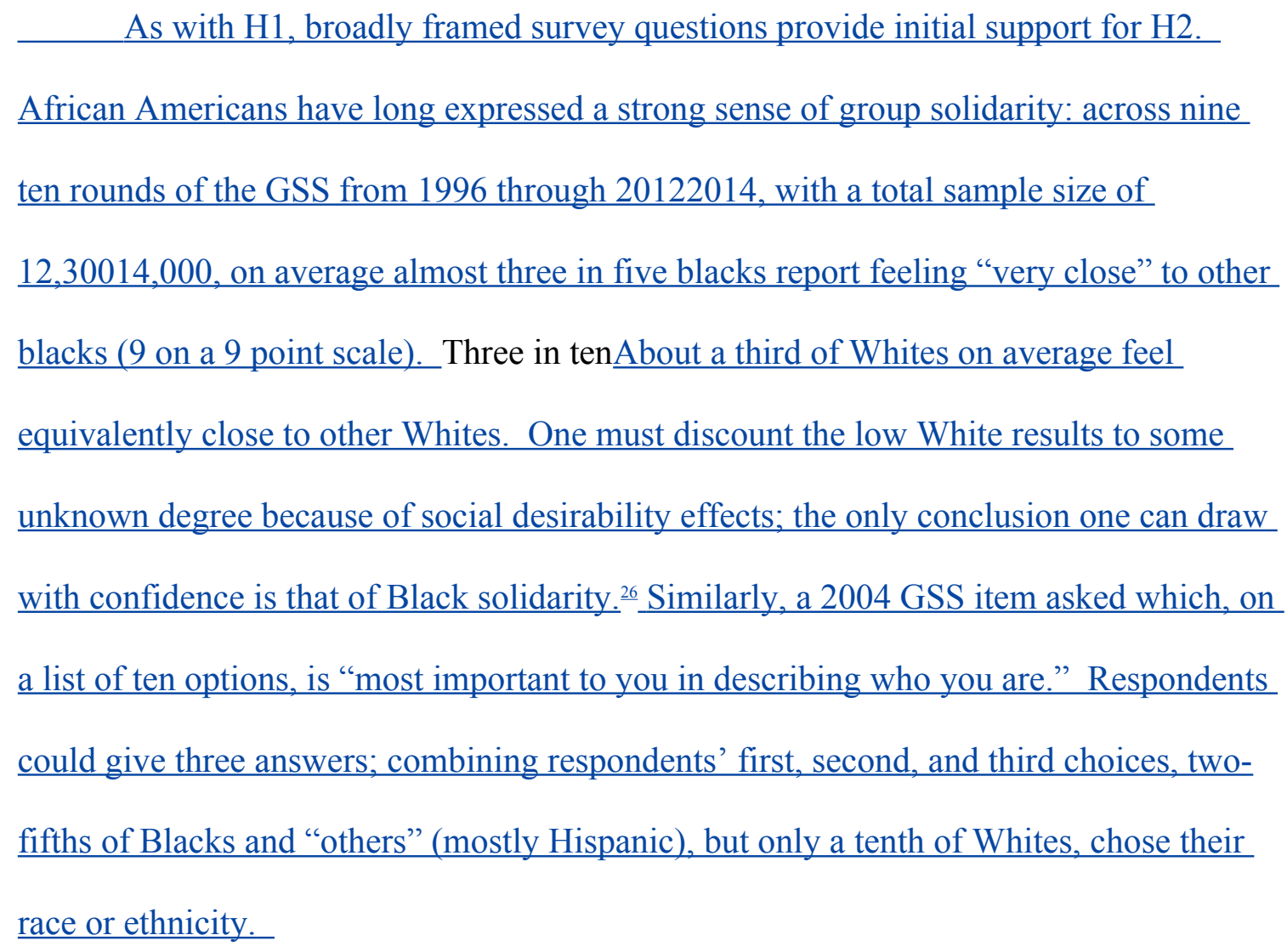

$\underline{\text { But Blacks' racial consciousness and solidarity need not imply rejection of mul- }}$ $\underline{\text { tiracialism or of an identity as mixed race. From } 1982 \text { forward, every relevant GSS sur- }}$ vey has shown stronger support among Black than White respondents for interracial marriage, by twenty percentage points or more in the first decade. Blacks' support eventually became almost unanimous. In contrast to the opposition of almost all members of the 
Congressional Black Caucus on this issue, as early as 1995 half of Black, compared with just over a third of White, respondents to a Newsweek poll agreed that "the U.S. Census should add a 'multiracial' category to population surveys so some people aren't forced to deny part of a family member's heritage by having to choose a single racial category" (authors' analysis of (Newsweek 1995)).

These data underlie the second hypothesis, predicting both Black endorsement of racial singularity and Black acceptance of racial mixture or multiple heritages in DNA ancestry tests. Given the weight of social desirability, we do not anticipate strong support for singular ancestry from Whites despite our theoretical prediction. All of those expectations are borne out in the vignette survey. Consider again Table 3. Averaging across both "self" and "other" vignettes, African Americans are more likely than most other groups to express pleasure at single-continent-of-origin outcomes. Just over three-fifths (61.5\%) do so, compared with the same proportion of Hispanics (60\%), but only $48 \%$ of multiracials and $45.5 \%$ of both Whites and Asian Americans. ${ }^{27}$ The differences between Blacks and Whites, as we noted above, is highly significant.

However, and crucially for $\mathrm{H} 2$, Blacks are also more likely than some other groups to express pleasure at multiple-continent-of-origin outcomes. The proportion is smaller, $41.5 \%$, but it remains higher than among Whites (28.5\%) or Asian Americans

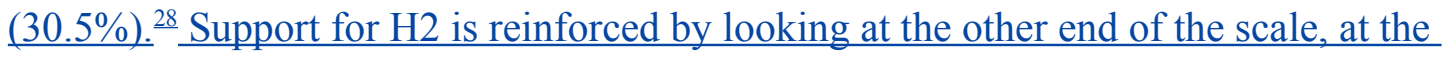
proportions expressing displeasure at the purported DNA test results (results not shown). As our theory would suggest, more Whites (17\%) and Asian Americans (20\%) than Blacks $(13 \%)$ were displeased with tests showing a plural ancestry for themselves as the vignette subject. ${ }^{29}$ Table 3 row 2 shows that African Americans expect members of other 
races to be displeased with plural results - again suggesting that blacks see themselves as distinctive, in this case distinctively open to multiple ancestries. ${ }^{30}$ -

With regard to the question of whether the respondent trusts the DNA ancestry test results, we have already reported very little difference across groups for H1. A similar pattern holds with regard to $\mathrm{H} 2$ (results not shown). As we reported above, overall three-fifths of the respondents would find the DNA test trustworthy. There are only minor differences across the five groups with regard to whether respondents would find compelling test results showing either singular or multiple ancestry. Blacks are in the middle of the range.

The most interesting feature of this question is its reinforcement of the pattern found in the newspapers' portrayal of DNA and race. As Table 1 and Figure 2 showed, the media consistently report more single group than multiple group results in articles on genetics and race. We cannot claim causality here, but we note that across the board, respondents trust single group results even more than they trust plural group results. Overall, $54 \%$ find the former believable, compared with $71 \%$ who find the latter believable; the difference is highly statistically significant. Furthermore, as Table 3 shows, nine of the ten within-group comparisons show that respondents would be more "pleased" with singular than with plural test results in the vignettes. Thus, in addition to revealing systematic differences between Blacks and other groups of Americans, the vignette study shows that DNA ancestry tests, like newspapers, do more to reinforce than to dissolve racial categories in the understanding of the American public.

Returning directly to $\mathrm{H} 2$, the results in Table 4 , with regard to identity or selfunderstanding, again show Blacks' distinctive commitment to singular racial ancestry in 
combination with their acceptance of multiple heritages. Averaging across the two conditions (how would you be affected, how would another person be affected), Blacks are much more likely than any other group to say that discovery of a singular ancestry would affect their identity "a lot." Agreement ranged from 47.5\% among African Americans down to $24.5 \%$ among whites. ${ }^{31}$ The difference in means in responses between Black and White respondents on this dimension is highly significant $(t$-statistic $=6.94, p$ value $=0.00$ ). Crucially for $\mathrm{H} 2$, the same result holds for the discovery of a plural ancestry; Blacks anticipate more impact regardless of what the DNA test reveals. Agreement that a multiple heritage would affect identity ranges from $42.5 \%$ among African Americans down to $24 \%$ among Whites, with a difference-in-means $t$-statistic of $\underline{5.83(p \text {-value of } 0.00))^{32}-}$

As our theory predicted, the most historically subordinated group held a stronger commitment to its denigrated racial label than other groups held did with regard to their own labels, and it held a stronger commitment to its denigrated racial label than to the proffered alternative. But, arguably due to their desire to mend the broken chain of ancestral connections, Blacks' positive response to racial singularity was almost matched by their positive response to racial multiplicity.

\section{| EXPLORING RESPONSES TO DNA ANCESTRY TESTS}

Both hypotheses have received strong support; despite the history of racial science, Blacks are more pleased with and responsive to DNA ancestry testing than are other groups, and Blacks' search for roots enables them to engage positively with the ideas of both single and multiple ancestral lines. They are not unique; the pattern among Latinos 
resembles that of Blacks at many points, and the other groups tend to be quantitatively rather than qualitatively different. However, in the time-honored tradition of social science, the vignette survey raises at least as many questions as it answers. Why are many Americans, especially African Americans, open to the links between race with biology that are implicit in DNA ancestry tests, and why are they attracted to multiple as well as singular racial lineages? Newspaper stories about individuals who have actually done DNA ancestry testing provide some clues to addressing the puzzles opened by the vignette survey described above. They also enrich our understanding of what the print media are teaching Americans about the links between genetics and race.

We begin to explore these questions with another content analysis of a different $\underline{\text { set of newspaper articles from those described above. , We again using used Lexis-Nexis }}$ Academic's database of U.S. newspapers and identifiedying articles through search terms meant to be somewhat but not too overinclusive. We began with the same search terms as in the automated content analysis, but constrained the search to include only articles that also used (in the same sentence) stems related to particular groups: Asian, Asian American, White, Pacific Islander, Native American, Alaskan Native, Latino/a, Hispanic, African American, Black, and Afro American (and their plurals or other variants). We again included keywords in the query to eliminate many extraneous articles.

The search yielded 717 articles from 1980 to 2009; its manageable size permitted hand coding and qualitative evaluation. The unit of analysis is unique profiled individuals, of whom there are 131. Eighty-three (64\%) identified as African American, thirty-four (26\%) as White, six as Hispanic, seven as racially mixed, and one was unknown.$\underline{33}$ This is far from a random sample of test-taking experiences since the 
analysis reflects five layers of selection: people who took a DNA ancestry test, whether they took Y-DNA, mitochondrial mt- DNA, or autosomal, tests; whether a journalist profiled them; what they told the journalist; and what appeared in the newspaper. These articles tell us about the social practices of a self-selected group as filtered through journalists' stories_-not about demographics or genealogy.

Nonetheless, the stories are illuminating, and so far as we know this is the first and only complete set of print media articles about DNA ancestry testing. Using the same coding rubric as with the automated content analysis (discussed above), DNA tests (presumably autosomal) showed mixed ancestry, usually African and European, for twofifths of the Blacks ( 33 people). T; tests for the remaining three-fifths (50 people) pointed to a singular heritage, generally by providing a link to a tribe or geographic area in Africa through Y-DNA or mt-DNA testing. In contrast, test results for a higher proportion - almost three-fifths — of the Whites (19 people) showed multiple ancestries, as did test results for all six Hispanics. Overall, singular racial ancestry predominated over multiple ancestries ( $56 \%$ and $44 \%$ of the stories, respectively); with some exceptions, test-takers - or the journalists who write about them — seem more interested in information about a single maternal or paternal lineage than in the range of their heritage. ${ }^{34}$

From a qualitative perspective, testers' responses to the DNA results clustered in three themes, each of which evoked both positive and negative reactions. First, some people simply wanted any relevant information, and were either pleased to receive it, or dismayed that they did not receive what they were looking for, or did not trust it. This reason corresponds to the "broken chain" theory behind our first hypothesis-members 
of some groups turn to DNA ancestry testing because they cannot use conventional genealogical techniques to trace their roots, and blacks Blacks have a uniquely strong motivation to use the only individual resource not stolen by slave traders. On the positive side, "when a radio host in Chicago revealed at a Kwanzaa festival last year that he was of Mende descent, several attendees who had received the same DNA result gathered to trade notes, a moment some said they found especially meaningful because slave owners made a point of separating Africans from the same tribes to prevent them from communicating" (Harmon 2005). On the negative side, some articles reflected the view of the author Pearl Duncan, who was "terrified of finding a racist or a separatist on my family tree" (Duncan 2004, p. _). Even she, however, found a source of meaning in the use of DNA tests, asserting that she nonetheless "would not be stopped from claiming my heritage" (Duncan 2004, p. .).

A second theme is more focused - a desire to know and explore the range and relative proportions of ancestral lines. People with this motivation use autosomal tests, although that technical fact is seldom reported in the newspaper stories. This motivation corresponds to the second half of the theory behind $\mathrm{H} 2$ : people in a socially inferior position are more likely to be positive about, or at least accepting of, multiple ancestral lines than are people in a socially superior position.

$\underline{\text { Results showing multiplicity may be revelatory. One tester told a reporter that, }}$ after explanations of how DNA tests work and what her own surprising results showed, "her perspective on race has totally changed. 'It's a , generating a "real paradigm shift. I will never look at race in the same way" "(Karen Hill, quoted in [(Zamora 2006)). Even more dramatically, Wayne Joseph "grew up a Black American" with a strong racial 
identity. He expected his DNA test to "come back about 70 percent African and 30

percent something else." Upon receiving the results, however, "I was floored." He was found to be 57\% Indo-European, 39\% Native American, and 4\% East Asian-no African ancestry at all. "For almost a year, Joseph searched his soul.... Before the test, 'I was unequivocally Black. Now I'm a metaphor for America" "(Kalb 2006), (Kalb 2006, p. 55).

Results showing multiplicity may also cause dismay; Snoop Dogg was not the only tester eager for a re-vote upon discovering how much of his ancestry was White. One member of a genealogical group "was crushed to learn that her line of male ancestors traced back to a White Italian, and not a Black resident of Madagascar as she had expected. 'She couldn't get past it. ... She ordered more tests'" (Willing 2006), p. 4A, quoting a testing expert). Similarly, Lisa Lee, a former Black Power activist, similarly discovered that she had no African ancestry on father's side. "What does this mean; who am I then? For me to have a whole half of my identity to come back and say, 'Sorry, no African here,' it doesn't even matter what the other half says. It just negates it all.... It doesn't fit, it doesn't feel right" (Harmon 2005, p. 18).

A third theme focused on a yet more specific set of links in the broken chain-a search for information about particular genealogical lines or ancestral locations. People with this motivation goal use mt-DNA or Y-DNA tests. Their motivation corresponds to the first half of the theory behind $\mathrm{H} 2$ : People seeking to either reinforce social superiority or counteract social inferiority are especially pleased to discover a lineage that they can cherish. Mika Stump grew up in foster homes, knowing nothing of her roots except that she is Black. A DNA test showed "strong similarities between Stump's genetic code and 
the Mende and Temne people of Sierrra Leone.... Now, 'I have a place where I can go back and say, "This is who I am; this is my home." That's something I never, ever expected to say"” (Willing 2006, p. 4A p. _). Reverend Al Simpson of Chicago traveled to Sierra Leone in order to give tribal elders of the village of Lunsar the test results showing his Temne lineage. "“Five hundred years ago my DNA was removed from here by slave traders and taken to America, so I'm coming back for my seat. My seat's been vacant." He asked for a Temne name in order " "to reclaim what was taken away from me"' (Gibson 2007) (Gibson 2007, p. .). On the other end of the social hierarchy, the Centre for Forensic Investigation at Glasgow Caledonian University announced its "intention to have DNA swabbing kits in all the tourist information offices and hotel lobbies across the UK, so people can go and pick up a kit for a few pounds then post it off to us and we will do the DNA tests for them." The Scottish tourist industry hopes that "DNA testing will be a draw for ancestral tourists who might want to "walk in the footsteps of their ancestors"” (Lei 2007, p. _). (Lei 2007).

The search for particular connections may extend beyond the location of one's ancestors to contemporary family ties. Testing revealed a close genetic link between Herman Mason, Jr. and Augustin Gouayou, a recent immigrant to the United States. "Gouayou, 36, can hardly believe his good fortune. The reunion has given childhood lessons about the slave trade and the African diaspora more personal meaning. 'You can't change history, but for me that was one, if not the best moment I've gotten since I came here [to the United States],' Gouayou said. This milestone now has the Barton-Thomas clan planning a trip to Cameroon," while Mason "is even more driven to learn more about his family's history, particularly its African and slave roots, and document it on paper and 
film. 'There will be plenty for me to research for the rest of my life'" (Reid 2007), p. 1B). . Another example: Although Pat's genealogical research persuaded her of "Hottentot" ancestors, a mitochondrial DNA test showed descent from the Akan of Ghana. She has since "established a friendship with a Ghanaian neighbor and has embarked on research into the history and culture of the Akan.... 'I bought my first Ghanaian flag last year'"'(Nelson 2008) 770-771) ${ }^{35}$

The themes may, of course, overlap. Even as a ten year old, Gates sought general information about his forebears, more focused information about his African heritage, and particular knowledge of specific ancestors: "I was searching not just for the names of my ancestors but for stories about them, the secrets of the dark past of Negroes in America.... Eventually ... I even allowed myself to dream about learning the name of the tribe we had come from in Africa" (Gates Jr. 2008), p. 5).

Overall, the themes revealed by these articles parallel and give depth to the themes explored in the quantitative analyses of the vignette survey. For the most part, profiled African Americans express enthusiasm about the use of genetic ancestry testing, particularly insofar as it can help bridge the chasms left in their genealogical record. In addition, we find meaningful distinctionsengagement in the articles regarding the themeswith both of ancestral singularity and ancestral multiplicity.

\section{CONCLUSION}

Genetic ancestry testing is typically described as recreational, and people do indeed give test kits to their relatives for Christmas. Roughly a million people have submitted such kits to testing companies over the past decade - a large sample, but a tiny fraction of the 
world's, or even the United States', population. So why should scholars other than genealogists or genetic anthropologists explore the larger meanings underlying the enterprise?

We see several reasons. First, the number of participants in genetic genealogy and DNA ancestry testing may well grow. "Genotyping cost is asymptoting to free," such that within a generation "it will be easier to know someone's genome than their name" (Altman 2008). Testing Ancestry testing can now be done for roughly $\$ 100$. As costs have decreased, accuracy, speed, and the quantity and quality of comparison samples have dramatically increasedimproved (Royal et al., 2010; (Royal et al. 2010; Wagner et al. 2012). Market analysts predict that genealogical research will continue to grow rapidly, and "the speed and enthusiasm with which the American genealogy community has embraced genetics has been truly astounding" (Sykes 2012, p. 72).

As it becomes cheaper and technically better, DNA ancestry testing may not only expand among individuals but also develop broad policy implications. "[D]eterminations of ancestry or 'blood' affect citizenship rights throughout the world; the right of return of displaced people; membership in tribal bands ... and affirmative action eligibility.... Determining one's ancestry through genetic evidence would fundamentally transform these types of political identity. ... Genetics can affect questions of ethnic identity ... religious identity... family identity or caste" (Elliott and Brodwin 2002), p. 1469). Several countries are experimenting with the use of DNA tests to decide eligibility for inheritance or immigration, and Americans' responses to DNA ancestry tests might feed into debates about the role of multiracialism in collecting data and determining group and individual rights. 
Most central to our evidenceimportant here is the fact that purportedly recreational genetic testing speaks to and may help to shape individuals' moral and ideological understandings of race and selfhood. "DNA testing results have the power to potentially reshape how individuals think of themselves and their ethnic heritage. ... Genetic ancestry has the potential to separate us from, and bind us to, specific groups of people.... We now are likely at the tip of a potential paradigmatic shift in how human ties are viewed and measured" (Hirschman and Panther-Yates 2008). For some, that is a terrifying prospect: "[T] he use of markers for individual identification"- - that is, DNA ancestry testing - risks "the subtle, sometimes inadvertent, reinscription of race at the molecular level" (Duster 2006). biological essentialism that is antithetical to the shared political values that should form the basis for unity" (Roberts 2011). For others, this potential paradigmatic shift is enormously attractive: If Americans are, in the Reverend Martin Luther King, Jr.'s terms, "caught in an inescapable network of mutuality, tied in a single garment of destiny," then accepting the idea that socially defined races have a biological element can work to the benefit of all. "Black and white citizens are bound together in this country at the most fundamental level possible - the level of the genome. And it turns out that Dr. King's stirring conclusion - that 'whatever affects one directly, affects all indirectly—has been literally true genetically of these two groups of the American people for a very long time" (Gates Jr. 2013). ${ }^{37}$

Two media content analyses and two new surveys cannot adjudicate these widely disparate views of the implications of DNA ancestry testing. Our evidence nonetheless enables us to conclude that, at least at the individual level, the dire concerns are not 
empirically supported. The media emphasize single rather than multiple lineages, but they also include stories about plural ancestry. The GSS shows widespread public support for DNA ancestry testing, especially though not uniquely among African Americans. The vignette survey shows African Americans to be disproportionately pleased with and influenced by hypothetical results of such a test compared with other Americans, and to embrace multiple ancestral lineages as well as singular connections to Africa. People want to forge some of the links in the broken chain of their heritage, even if the result is not exactly what they had hoped for. In so doing, the American public seems prepared to absorb the information available in this new technology without either succumbing to the biologization of race or drawing apparently immutable boundaries around groups. For most people, ancestry testing is "one part of who you are, not your identity, only as much of your identity as you want it to be." Whether that clear-headed view persists once it becomes "easier to know someone's genome than their name" remains an open question.

Corresponding author: Jennifer Hochschild, Henry LaBarre Jayne Professor of dd Government and Professor of African and African American Studies, Harvard University, 1737 Cambridge St., Cambridge, MA 02138. E-mail: hochschild@gov.harvard.edu

\section{$\underline{\text { References }}$}

Altman, Russ (2008). Genotyping Cost Is Asymptoting to Free. Building Confidencehttp://rbaltman.wordpress.com/2008/10/08/genotyping-cost-is-asymptoting-tofree/http://rbaltman.wordpress.com/2008/10/08/genotyping-cost-is-asymptoting-to-free/. American Anthropological Association (1998). "Statement on "Race"." American Anthropologist 100: 712713.

Anderson, Amy (2014) "Opportunity Is About to Knock So Get Ready to Open Your Door." Forbeshttp://www.forbes.com/sites/amyanderson/2014/11/23/opportunity-is-about-to-knock-soget-ready-to-open-your-door/,November 23, http://www.forbes.com/sites/amyanderson/2014/11/23/opportunity-is-about-to-knock-so-getready-to-open-your-door/. 
Anderson, Benedict (1983). Imagined Communities: Reflections on the Origin and Spread of Nationalism. New York, Verso.

Ataiyero, Kayce. (2007). "Determining Ancestry Tough for Some Blacks," " Chattanooga Times Free Press. March 11 p. A5.

Cavalli-Sforza, L. Luca, et al. (1994). The History and Geography of Human Genes. Princeton NJ, Princeton University Press.

Chong, Dennis and Reuel Rogers (2004). "Reviving Group Consciousness." The Politics of Democratic Inclusion. Wolbrecht, Christina and Rodney Hero, Ed. Philadelphia PA, Temple University Press: 45-74.

Cohn, Jay (2006). "The Use of Race and Ethnicity in Medicine: Lessons from the African-American Heart Failure Trial." Journal of Law, Medicine, and Ethics 34 (3): 552-554.

Collins, Nick. (2013). "DNA Ancestry Tests Branded 'Meaningless'." The Telegraph. March 7.p.

Duster, Troy (2006). "The Molecular Reinscription of Race: Unanticipated Issues in Biotechnology and Forensic Science." Patterns of Prejudice 40 (4-5): 427-441.

Elliott, Carl and Carl Brodwin (2002). "Identity and Genetic Ancestry Tracing." British Medical Journal 325 (7378): 1469-1471.

Espinosa, Lesle and Angela Harris (1997). "Afterward: Embracing the Tar Baby -- Lat-Crit Theory and the Sticky Mess of Race." California Law Review 85: 1585-1645.

Falconer, Bruce. (2012). "Ancestry.Com's Genealogical Juggernaut." Businessweek. September 20, 1.

Farnham, Alan (2012) "Who's Your Daddy? Genealogy Becomes \$1.6b Hobby." ABC Newshttp://abcnews.go.com/Business/genealogy-hot-hobby-worth-16b-mormons/story?

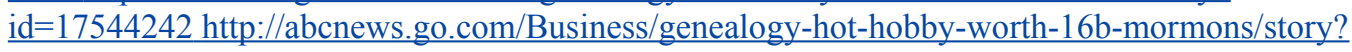
$\underline{\mathrm{id}=17544242 \text {. }}$.

Finch, Janet (1987). "The Vignette Technique in Survey Research." Sociology 21 (1): 105-114.

Frost, Robert (1920). "The Road Not Taken." Mountain IntervalEd. New York, Henry Holt.

Frudakis, Tony (2008). "The Legitimacy of Genetic Ancestry Tests." Science 319 (5866): 1039-1040.

Fullwiley, Duana (2007). "The Molecularization of Race: Institutionalizing Human Difference in Pharmacogenetics Practice." Science as Culture 16 (1): 1-30.

Gates Jr., Henry Louis (2008). In Search of Our Roots: How 19 Extraordinary African Americans Reclaimed Their Past. New York, Crown Publishers.

--- (2013) "Exactly How 'Black' Is Black America?" The Roothttp://www.theroot.com/articles/history/2013/02/how_mixed_are_african_americans.4.html http://www.theroot.com/articles/history/2013/02/how_mixed_are_african_americans.4.html.

Gibson, Lydialyle. (2007). "Long Way Home." University of Chicago Magazine.

Golbeck, Natasha and Wendy Roth (2012). "Aboriginal Claims: DNA Ancestry Testing and Changing Concepts of Indigeneity." Biomapping Indigenous Peoples: Towards an Understanding of the Issues. Berthier-Foglar, Susanneet al., Ed. Amsterdam, Rodopi: 415-432.

Harmon, Amy. (2005). "Blacks Pin Hope on DNA to Fill Slavery's Gaps in Family Trees " New York Times. July 25. p. A1.

Hirschman, Elizabeth and Donald Panther-Yates (2008). "Peering Inward for Ethnic Identity: Consumer Interpretation of DNA Test Results." Identity 8 (1): 47-66.

Hochschild, Jennifer, et al. (2012). Creating a New Racial Order: How Immigration, Multiracialism. Genomics, and the Young Can Remake Race in America. Princeton NJ, Princeton University Press.

Hopkins, Daniel and Gary King (2010). "A Method of Automated Nonparametric Content Analysis for Social Science." American Journal of Political Science 54 (1): 229--247.

Jones, James (1992). Bad Blood: The Tuskegee Syphilis Experiment, New and Expanded Edition. New York, Free Press.

Joseph, Peniel (2007). Waiting 'Til the Midnight Hour: A Narrative History of Black Power in America New York, Holt.

Kalb, Claudia. (2006). "In Our Blood." Newsweek. February 6, 47-55.

Lei. Hsien-Hsien (2007) "DNA-Supported Ancestral Tourism." Eve on DNAhttp://www.eyeondna.com/2007/06/11/dna-supported-ancestral-tourism/.June 11, http://www.eyeondna.com/2007/06/11/dna-supported-ancestral-tourism/.

Morton, Sunny Jane. (2012). "5 Questions with Henry Louis Gates Jr." Family Tree Magazine. JulyAugust, 
Nelson, Alondra (2008). "Bio Science: Genetic Genealogy Testing and the Pursuit of African Ancestry." Social Studies of Science 38 (5): 759-783.

Newsweek (1995). Newsweek Survey: What Is Black? Princeton NJ, Princeton Survey Research Associates [producer]

Omi, Michael and Howard Winant (1994). Racial Formation in the United States. New York, Routledge.

Phalen, Jo, et al. (2013). "The Genomic Revolution and Beliefs About Essential Racial Differences: A Backdoor to Eugenics?" American Sociological Review 78 (2): 167-191.

PRWeb (2013) "Man Converts to Judaism after Test from DNA Spectrum Uncovers Jewish Ancestry." http://www.prweb.com/releases/2013/8/prweb11063895.htm http://www.prweb.com/releases/2013/8/prweb11063895.htm.

Reid, S.A. (2007). "From 2 Races and 2 Sisters Come 1 Circle." Atlanta Journal-Constitution. August 20. p. 1 B.

Roberts, Dorothy (2011). Fatal Invention: How Science, Politics, and Big Business Re-Create Race in the Twenty-First Century. New York, New Press.

Root, Maria (1993) "Bill of Rights for People of Mixed Heritage." http://www.drmariaroot.com/doc/BillOfRights.pdf http://www.drmariaroot.com/doc/BillOfRights.pdf.

Roth, Wendy (2012). 'Not Everybody Knows That I'm Actually Black': The Effects of DNA Ancestry Testing on Racial and Ethnic Identities. Vancouver, British Columbia, University of British Columbia, Department of Sociology

Roth, Wendy and Katherine Lyon (2013). Genetic Ancestry Tests and Race: Who Takes Them, Why, and How Do They Affect Racial Identities? Vancouver, British Columbia, University of British Columbia, Department of Sociology

Royal, Charmaine and Georgia Dunston (2004). "Changing the Paradigm from 'Race' to Human Genome Variation." Nature Genetics 36: S5-S7.

Royal, Charmaine, et al. (2010). "Inferring Genetic Ancestry: Opportunities, Challenges, and Implications." American Journal of Human Genetics 86 (5): 661-673.

Salkin, Allen. (2008). "When in Doubt, Spit It Out." New York Times. September 12. p. 1(L).

Shelby, Tommie (2005). We Who Are Dark: The Philosophical Foundations of Black Solidarity. Cambridge, MA, Harvard University Press.

Shriver, Mark and Rick Kittles (2008). "Genetic Ancestry and the Search for Personalized Genetic Histories." Revisiting Race in a Genomic Age. Koenig, Barbaraet al., Ed. New Brunswick NJ, Rutgers University Press: 201-214.

Sykes, Brian (2012). DNA USA: A Genetic Portrait of America. New York:, Liveright Publishing Co.

Ture, Kwame and Charles Hamilton (1992). Black Power : The Politics of Liberation. New York, Vintage.

Venter, J. Craig (2007). A Life Decoded: My Genome: My Life. New York, Viking.

Wagner, Jennifer, et al. (2012). "Tilting at Windmills No Longer: A Data-Driven Discussion of Dtc DNA Ancestry Tests." Genetics in Medicine 14 (6): 586-593.

Washington, Harriet (2006). Medical Apartheid: The Dark History of Medical Experimentation on Black Americans from Colonial Times to the Present. New York, Doubleday.

Willing, Richard. (2006). "DNA Rewrites History for African-Americans." USA Today. February 1.p.

Zamora, Jim. (2006). "DNA Workshop Upends Notion of Race for Many." . ." San Francisco Chronicle. June 11.p. B1. 


\section{Figures}

\section{| Figure 1: Google NGrams for "DNA," "Genetic[s]," AND "Genomic[s]," 1940-2008}

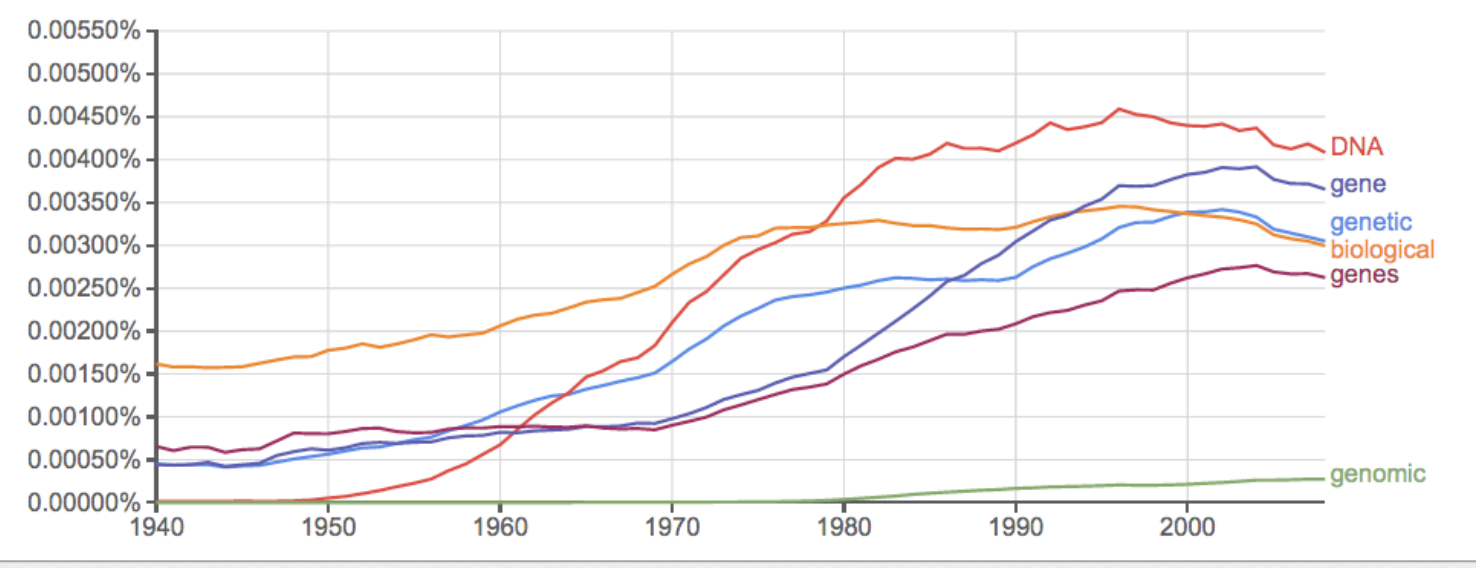

Note: The y-axis represents the percentage of Ngrams that contained the above words out of the universe of Ngrams in English-language books. 
Figure 2: NewsPaper Articles Per Year AdDressing RaCe or AnCESTRy AND DNA, $\underline{1988-2009^{38}}$

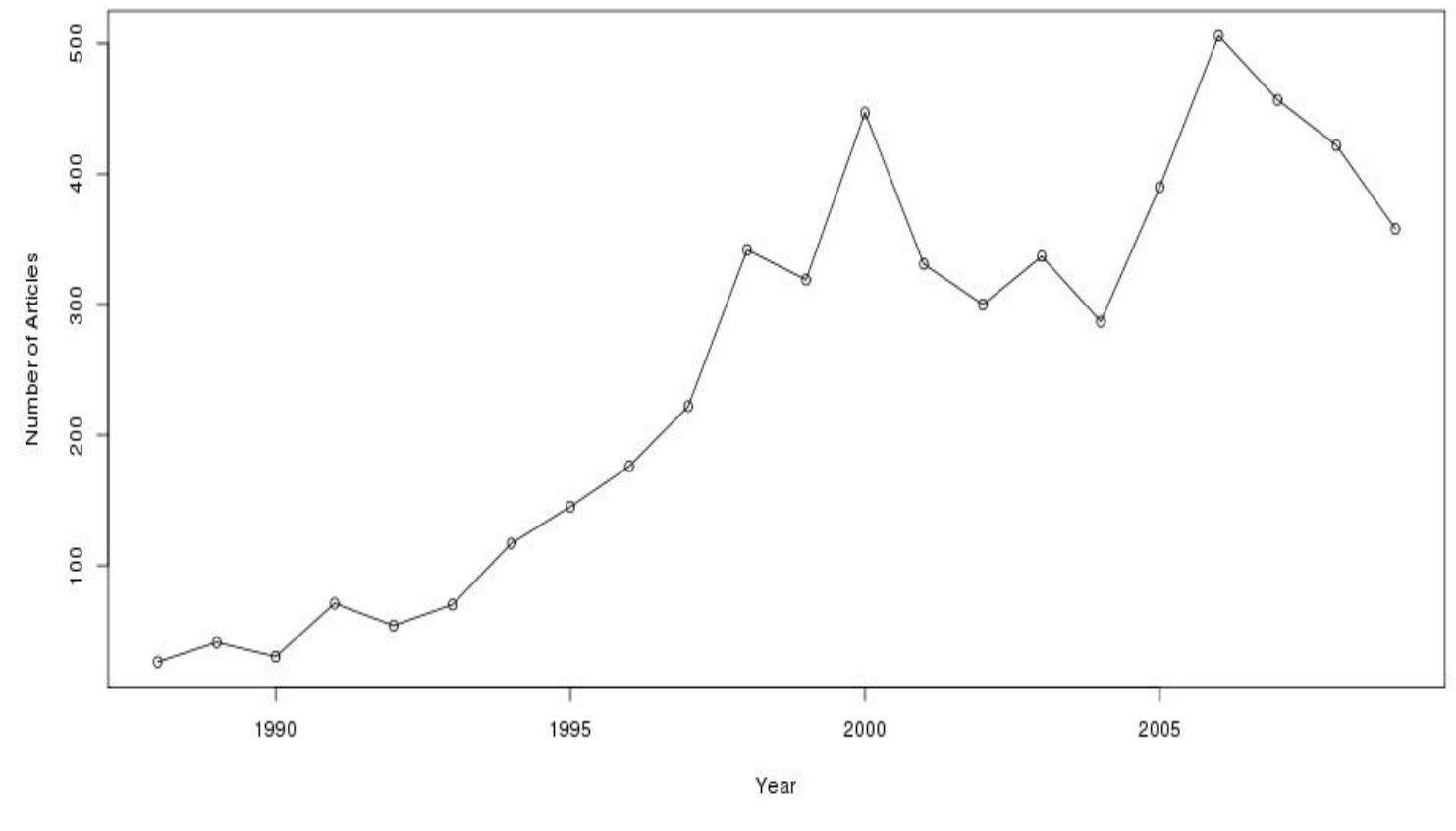


Figure 3: Proportion of Newspaper Articles on Plurality, Singularity, or Both, $\underline{1988-2009}$

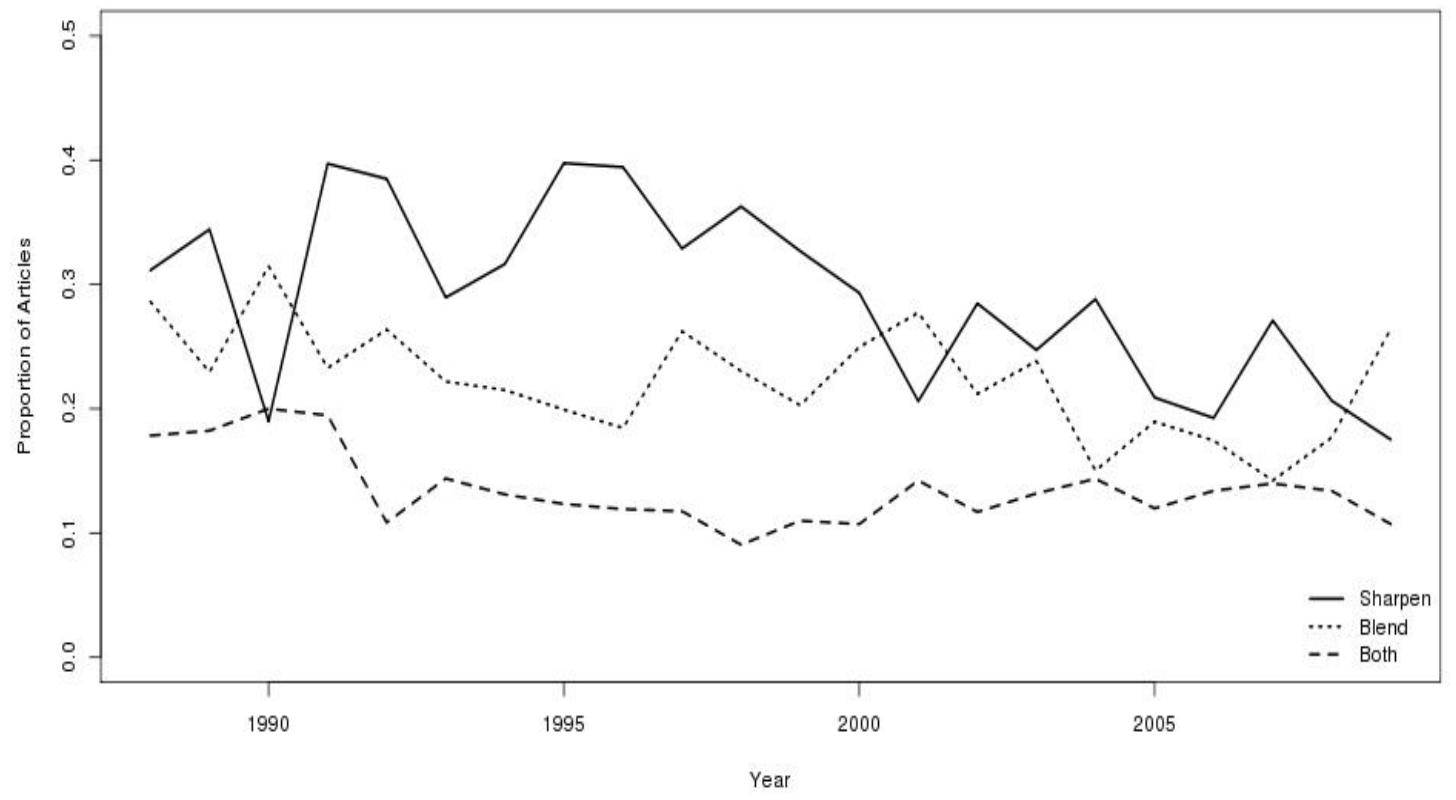


Figure 4: Map Showing Highlighted Continents, VignetTe Survey, 2010

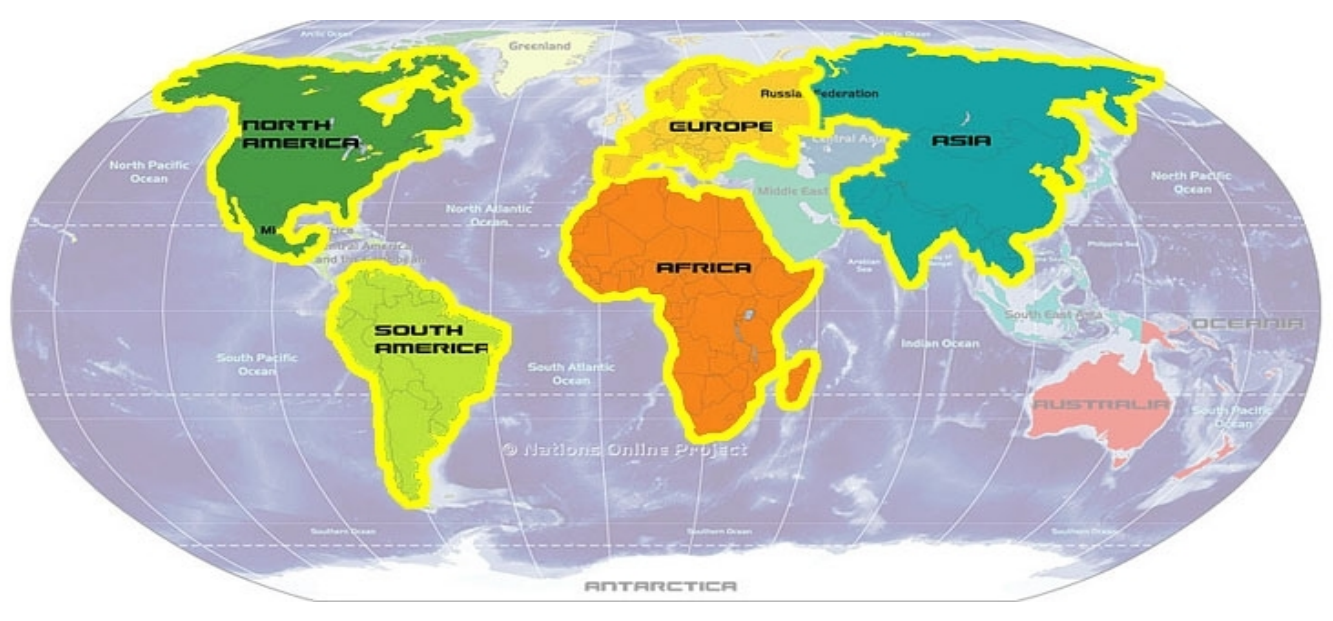


$\underline{\text { Tables }}$ 
Table 1: Proportion of Newspaper Articles Focused on Plurality, SINGULARITY, OR BOTH, TOTAL 1969-2009

\begin{tabular}{|c|c|c|c|}
\hline Substantive Category & Estimate & $(S E)$ & $\begin{array}{l}\text { 95\% Confidence } \\
\text { Interval }\end{array}$ \\
\hline Plural & $\underline{0.21}$ & $(0.018)$ & $(0.24,0.17)$ \\
\hline Singular & 0.30 & $(0.021)$ & $(0.34,0.26)$ \\
\hline Both & 0.09 & $(0.011)$ & $(0.11,0.06)$ \\
\hline Neither & $\underline{0.41}$ & $(0.022)$ & $(0.45,0.36)$ \\
\hline
\end{tabular}


TABLe 2: Illustrative Items IN THE VignetTe SuRVey, 2010

Singularity Prompts for an African American respondent:

1. "Isabella is a woman [Or, Michael is a man...] who identifies as African American. She has taken a DNA test indicating that her female lineage can be traced primarily to Africa. If you were Isabella, how would you feel about that?"399

2. "Isabella is a woman [Or, Michael is a man...] who identifies as [a randomly chosen race other than African American]. She has taken a DNA test indicating that her female lineage can be traced primarily to [the continent appropriate for that race]. How would you expect Isabella to feel about that?"

Plurality Prompts for an African American respondent:

3. "Emily is a woman [Or, Christopher is a man...] who identifies as African American. She has taken a DNA test indicating that her female lineage is spread across Europe or the Middle East, Africa, North America, Latin America or Spain, and Asia. If you were Emily, how would you feel about that?"

4. "Emily is a woman [Or, Christopher is a man...] who identifies as African American. She has taken a DNA test indicating that her female lineage is spread across Europe or the Middle East, Africa, North America, Latin America or Spain, and Asia. How would you expect Emily to feel about that?" 


\begin{tabular}{|c|c|c|c|c|c|c|c|c|c|c|c|c|}
\hline & \multicolumn{2}{|c|}{$\underline{\text { Blacks }}$} & \multicolumn{2}{|c|}{ Whites } & \multicolumn{2}{|c|}{$\underline{\text { Hispanics }}$} & \multicolumn{2}{|c|}{\begin{tabular}{|l} 
Asian \\
Americans \\
\end{tabular}} & \multicolumn{2}{|c|}{$\begin{array}{l}\text { Multiraci } \\
\underline{\text { als }}\end{array}$} & \multicolumn{2}{|l|}{$\underline{\text { All }}$} \\
\hline & $\begin{array}{l}\underline{P} \\
\underline{l} \\
\underline{u} \\
\underline{r} \\
\underline{a} \\
\underline{l}\end{array}$ & $\frac{\text { Sing }}{\underline{\text { ular }}}$ & $\begin{array}{l}\underline{P} \\
\underline{\underline{l}} \\
\underline{u} \\
\underline{r} \\
\underline{a} \\
\underline{l}\end{array}$ & $\begin{array}{l}\frac{S i}{n g} \\
\frac{u l}{a r} \\
\underline{a r}\end{array}$ & $\begin{array}{l}\underline{P} \\
\underline{\underline{u}} \\
\underline{u} \\
\underline{r} \\
\underline{a} \\
\underline{\underline{l}}\end{array}$ & $\begin{array}{l}\frac{\operatorname{Sin}}{g u l} \\
\underline{a r}\end{array}$ & $\frac{\frac{P l}{u r}}{\underline{a l}}$ & $\begin{array}{l}\frac{\operatorname{Sin}}{g u l} \\
\underline{a r}\end{array}$ & $\begin{array}{l}\underline{P} \\
\underline{\underline{l}} \\
\underline{u} \\
\underline{\underline{a}} \\
\underline{a} \\
\underline{\underline{l}}\end{array}$ & \begin{tabular}{|l|}
$\underline{S}$ \\
$\underline{i}$ \\
$\underline{n}$ \\
$g$ \\
$\underline{u}$ \\
$\underline{l}$ \\
$\underline{a}$ \\
$\underline{r}$
\end{tabular} & $\frac{\underline{P l}}{\underline{u r}}$ & $\begin{array}{l}\frac{S i}{n g} \\
\underline{u l} \\
\underline{a r}\end{array}$ \\
\hline 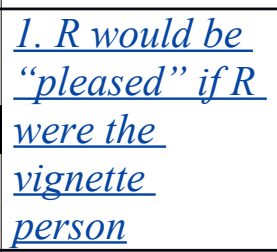 & $\underline{41}$ & $\underline{65}$ & $\underline{29}$ & $\underline{38}$ & $\underline{41}$ & $\underline{57}$ & $\underline{28}$ & $\underline{49}$ & $\underline{42}$ & $\underline{41}$ & $\underline{33}$ & $\underline{45}$ \\
\hline $\begin{array}{l}\text { 2. R expects } \\
\text { vignette } \\
\text { person to be } \\
\text { "pleased" } \\
\end{array}$ & $\underline{42}$ & $\underline{58}$ & $\underline{28}$ & $\underline{53}$ & $\underline{45}$ & $\underline{63}$ & $\underline{33}$ & 42 & $\underline{37}$ & $\underline{55}$ & $\underline{32}$ & $\underline{55}$ \\
\hline$\underline{N}$ & $\underline{196}$ & $\underline{196}$ & 227 & 232 & $\underline{192}$ & $\underline{195}$ & $\underline{220}$ & $\underline{231}$ & $\underline{202}$ & 202 & $\underline{1037}$ & $\underline{1056}$ \\
\hline
\end{tabular}




\begin{tabular}{|c|c|c|c|c|c|c|c|c|c|c|c|c|}
\hline \multicolumn{13}{|l|}{ CELL) } \\
\hline & \multicolumn{2}{|c|}{ Blacks } & \multicolumn{2}{|c|}{ Whites } & \multicolumn{2}{|c|}{ Hispanics } & \multicolumn{2}{|c|}{$\begin{array}{l}\text { Asian } \\
\text { Americans }\end{array}$} & \multicolumn{2}{|c|}{ Multiracials } & \multicolumn{2}{|c|}{ All } \\
\hline & $\begin{array}{l}\underline{P} \\
\underline{l} \\
\underline{u} \\
\underline{r} \\
\underline{a} \\
\underline{l}\end{array}$ & $\begin{array}{l}\underline{S} \\
\underline{i} \\
\underline{n} \\
g \\
\underline{u} \\
\underline{\underline{l}} \\
\underline{a} \\
\underline{r}\end{array}$ & $\frac{\frac{P l}{u r}}{\underline{a l}}$ & $\begin{array}{l}\underline{S} \\
\underline{i} \\
\underline{n} \\
g \\
\underline{u} \\
\underline{l} \\
\underline{a} \\
\underline{\underline{r}} \\
\underline{\underline{u}}\end{array}$ & $\begin{array}{l}\underline{P} \\
\underline{\underline{u}} \\
\underline{u} \\
\underline{r} \\
\underline{a} \\
\underline{l}\end{array}$ & $\begin{array}{l}\underline{S} \\
\underline{i} \\
\underline{n} \\
g \\
\underline{u} \\
\underline{u} \\
\underline{a} \\
\underline{\underline{r}}\end{array}$ & $\begin{array}{l}\underline{P} \\
\underline{\underline{u}} \\
\underline{u} \\
\underline{r} \\
\underline{a} \\
\underline{l}\end{array}$ & $\begin{array}{l}\frac{S i}{n g} \\
\underline{u l} \\
\underline{a r}\end{array}$ & $\underline{\text { Plu }}$ & $\begin{array}{l}\underline{S} \\
\underline{i} \\
\underline{n} \\
g \\
\underline{u} \\
\underline{l} \\
\underline{a} \\
\underline{\underline{r}}\end{array}$ & $\frac{\frac{P l}{u r}}{\frac{u r}{a l}}$ & $\begin{array}{l}\underline{S i} \\
\underline{n g} \\
\underline{u l} \\
\underline{a r}\end{array}$ \\
\hline $\begin{array}{l}\text { 1. Results } \\
\text { would "matter } \\
\text { a lot" if } R \\
\text { were the } \\
\text { vignette person }\end{array}$ & $\underline{39}$ & $\underline{50}$ & $\underline{21}$ & $\underline{20}$ & $\underline{35}$ & $\underline{40}$ & $\underline{34}$ & $\underline{33}$ & $\underline{22}$ & 27 & $\underline{26}$ & $\underline{27}$ \\
\hline $\begin{array}{l}2 . \text { R expects } \\
\text { results to } \\
\text { "matter a lot" } \\
\text { to the vignette } \\
\text { person }\end{array}$ & $\underline{46}$ & $\underline{45}$ & $\underline{27}$ & $\underline{29}$ & $\underline{46}$ & $\underline{45}$ & $\underline{38}$ & $\underline{41}$ & 44 & $\underline{37}$ & $\underline{33}$ & $\underline{34}$ \\
\hline$\underline{N}$ & 194 & $\underline{193}$ & $\underline{226}$ & 233 & $\underline{190}$ & $\underline{192}$ & $\underline{221}$ & $\underline{229}$ & $\underline{194}$ & $\underline{187}$ & $\underline{1025}$ & $\underline{1034}$ \\
\hline
\end{tabular}


NOTES 
${ }^{1}$ Thanks to Natalie Padilla, Andrew Benitez, Anna Remus, Claire Wheeler, and especially Alex Crabill for invaluable research assistance. We are grateful for the help of Patrick Moynihan, Jeremy Freese, Penny Visser, two TESS reviewers, and the Knowledge Networks staff on the vignette survey. Further thanks to Eleanor Singer, Gail Henderson, Tom Smith, and Peter Marsden for enabling and helping to develop the General Social Survey items, and to anonymous reviewers, including two at The Du Bois Review, who helped us to develop and sharpen our arguments. We want to express deep appreciation to the many people who have shared their expertise on genomic science; we promised confidentiality, so we cannot thank them by name. This research was sponsored by the National Science Foundation through TESS (Time-sharing Experiments for the Social Sciences), the General Social Survey, and the Robert Wood Johnson Foundation through its Investigator Award in Health Policy Research.

${ }^{2}$ The canonical statement of race as a social construction is the United Nations Educational, Scientific, and Cultural Organization's Declaration on Race and Racial Prejudice (UNESCO 1979); however, examples in the academic literature abound (see e.g., (Anderson 1983); Bliss 2012;Bridges 2013; Gross 2008; Haney Lo'pez 1996; Morning 2011; (Omi and Winant 1994); Wimmer 2008).

${ }^{3}$ Some genomics researchers agree that group labels and precise racial boundaries are social inventions but nonetheless use a biological conception of race, at least in part, to foster their commitments to racial justice (Bliss 2012). Life scientists are more inclined than are social scientists to use biological conceptions of race, but disciplinary differences do not correspond exactly with views on race and biology (Morning 2011).

4 "Two roads diverged in a yellow wood. . . I took the one less traveled by/ And that has made all the difference-" (Frost $1920)$.

${ }^{5}$ This article ignores the possibility of taking both tests. People who do both are likely to have considerable knowledge about DNA ancestry testing and so are not relevant to our question of how the general public responds to the idea of genomic ancestry testing. (Roth and Lyon 2013) provide a good explanation of the types of tests, and analyze the ways in which knowledgeable users choose among them.

${ }^{6}$ That is the perspective from which Snoop Dogg's joke about the revelation of his Wwhite ancestry derives. Charles Barkley's response: "I'll just call you Wwhitey from now on" http://www.youtube.com/watch?v=Exz0yNdvksg

${ }^{7}$ Such a person may, hore _use DNA testing for more focused genealogical research or to find unknown relatives; however, the fact that newly discovered second cousins share genomic profiles implies nothing about the broader question of a biological component of racial identity or definition.

${ }^{8}$ Note that our theory operates at the level of individual attitudes, not at the level of collective political activity or policy stances. Given their long history as the subjects of disgraceful scientific "experiments" such as the Tuskegee syphilis study (Jones 1992); Reverby 2009; (Washington 2006) there are good reasons for African Americans' demonstrated wariness about scientific or governmental inquiries into the possible links between race and biology or genetics. The General Social Survey (GSS) has asked whether genetic testing (impliedly implicitly in the medical arena) will do more harm than good, or the reverse, four times since 1990. In all four years, Blacks were less likely than Whites (and Hispanics in 2010) to say that the good of genetic testing outweighs its harms, generally at a .01 level of statistical significance. (The questions were asked in 1990, 1996, 2004, and 2010. In 2010, they were part of our module on genetics and genomics, which has not yet been publicly released.) The relationships between individual enthusiasm for DNA ancestry testing, if our hypotheses are supported, and Bblacks' policy preferences with regard to genomic science remain to be investigated.

${ }^{9}$ Hence, Maria Root's well-known "Bill of Rights for People of Mixed Heritage" includes "the right . . . to identify myself differently in different situations ... [and] to change my identity over my lifetime - and more than once” (Root 1993). See more generally, Jennifer Hochschild and colleagues, 2012. -(Hochschild et al. 2012).

${ }^{10}$ Google Ngrams is a "corpus of digitized texts containing about $4 \%$ of all books ever printed." It includes about 5.2 million books, mainly of the type that libraries acquire since they are the source of the books that were-Google digitized. One cannot search the corpus of texts on the main site after 2008 (https://books.google.com/ngrams).

${ }^{11}$ The universe of articles came from Lexis-Nexis Academic's online database of U.S. newspapers, which encompasses everything from The New York Times to regional and local newspapers. It includes a smattering of trade publications, business journals, and law-oriented publications.

${ }^{12}$ We used the root of each keyword followed by an exclamation mark (!), to obtain all words formed by adding letters to the keyword's root (as in genetic, genetics, geneticist using the keyword "genetic!").

${ }^{13}$ See Jo Phalen and colleagues 2013(Phalen et al. 2013) for a smaller media analysis with similar results

${ }_{14}^{14}$ In collaboration with Eleanor Singer and Gail Henderson, we wrote a module of questions about genetics and genomics that were included in the 2010 GSS. The sample included 1077 respondents, representative of the national population of American adults. The data have not been released; sSo far as we know, this article is provides the first report of the results. ${ }^{15}$ That is, unlike that of most media scholars, our goal was not to explore newspapers' influence on people's level of attention, knowledge, policy priorities, or political views. We used these articles as an indicator of the kind of information to which the public is exposed.

${ }^{16}$ Since we intentionally chose over-inclusive search terms, many unrelated articles were swept into the database. We would have been concerned by a small percentage of unrelated articles, which would have suggested a possibly under- 
inclusive initial search. Ann Morning (2011) reports a broadly similar finding about textbooks.

${ }^{17}$ Arguably more Americans obtain information from television than from newspapers. Documentary series such as Henry Louis Gates Jr.'s "African American Lives" and "Faces of America," talk shows such as "The Oprah Winfrey Show" and "Dr. Oz," entertainment and variety shows such as "The Colbert Report" and "The George Lopez Show," or news shows such as "60 Minutes" or "20/20" have all have explored links between DNA technology and race or ancestry. We know of no complete database for television programs analogous to Lexis-Nexis, so we could not conduct similar analyses.

However, the information conveyed by television is likely to be similar to that of newspapers. Sometimes the similarity is literal: "African American Lives" and its successors profile celebrities whose experiences on the shows are the subjects of a fair number of the articles in print media. Snoop Dogg's experiences with DNA testing appeared on television and then in newspaper stories discussing the television show. More generally, in this arena television and the print media usually cover the same events and rely on the same experts - not surprising in a substantive topic that is new and unfamiliar to most reporters.

${ }^{18}$ We compared the samples in the vignette survey with demographic information in the 2010 American Community Survey. The samples are comparable to national averages, with two exceptions: respondents are slightly overeducated compared to the national average, and people in very high-income brackets are slightly underrepresented.

${ }^{19}$ The material in these vignettes and in the response categories was randomized in four ways, so question or response order effects are not a concern.

${ }^{20}$ Note two modifications of the basic research design, chosen so as to maximize external validity. First, since autosomal DNA tests cannot specify Latin America as an ancestral region, the vignette signaling Latino singularity included both

Europe and South America (and highlighted both continents on the map) rather than only one continent as in the other cases. Second, racial singularity prompts for multiracials (for whom we had no other group information) specified two continents chosen at random, whereas racial plurality was "spread across" several continents. Given that the two randomly-chosen continents might not match the multiracial respondent's own group identity (as we intended to be the case in the vignettes asking "how would you feel ... ?"), this choice might downwardly bias results from the first of the four vignettes. Thus our results are likely to be conservative estimates of the effects of that prompt for multiracials.

${ }^{21}$ We collapsed these variables to make the presentation and analysis more straightforward and to avoid obfuscating important patterns; however, the results are substantively similar when the answers are left disaggregated. We dropped write-in responses and non-responses from all analyses; results were weighted to reflect accurately either the national population or the particular racial or ethnic group. For other studies of responses to DNA ancestry test results see Jennifer (Hirschman and Panther-Yates 2008), Alondra Nelson (2008),Wendy (Roth 2012) and Natasha (Golbeck and Roth 2012). ${ }^{22}$ Lesle (Espinosa and Harris 1997) defend the use of the slightly controversial phrase "Black exceptionalism."

${ }^{23}$ As with the "pleased" results, we collapsed the three points on the displeasure end of the seven-point scale for ease of presentation. Average proportions in the other groups expressing displeasure are $11 \%$ for Hispanics and multiracials, $12.75 \%$ among Whites, and $15.25 \%$ among Asian Americans.

${ }^{24}$ As we did for the question about being pleased, we collapsed the top three response categories into one for ease of presentation. They were "completely believable," "mostly believable," and "somewhat believable."

${ }^{25}$ Responses to the question of whether the DNA ancestry test results are believable do not seem to be simply an indicator of the respondent's general trust in science or scientists. Across twenty-seven iterations of the GSS from 1973 through 2012, the racial differences in confidence in science are much greater than in the vignette survey. There were 35,890 respondents in these GSS's; $45 \%$ of Whites, $44 \%$ of "other" (mostly Hispanic), and only $28 \%$ of Blacks express "a great deal" of confidence in the scientific community. Results in the vignette survey do not echo the GSS results.

${ }^{26}$ Data are insufficient to report Hispanics' or Asian Americans' feeling of closeness to other members of their own group. See Dennis (Chong and Rogers 2004), among others, for further discussion of Black racial group consciousness.

${ }^{27}$ It remains unclear what Hispanics mean by endorsing singular racial ancestry-whether they think in terms of Whiteness, indigeneity, or "Hispanic" as a singular racial entity. It is similarly unclear what self-defined multiracials mean when they endorse a singular racial ancestry. Interviews would be a valuable follow-up, here as elsewhere.

${ }^{28}$ The fact that only $39.5 \%$ of multiracials express pleasure at DNA ancestry test results showing multiple ancestry might be an artifact of the way in which the survey was conducted. As reported above, since we did not know the exact ancestral combination among self-defined multiracials, we chose two continents at random for the multiple heritages vignette (and those two continents were highlighted on the accompanying map). If they were the "wrong" continents, multiracial respondents may have been confused or have rejected the supposed outcome of the test. As noted above, we need further investigation to understand why only $43 \%$ of Latinos endorsed multiple racial heritage; it might imply too much non-White ancestry, or might suggest that "Hispanic" is not a coherent racial category.

${ }^{29}$ The comparable proportions for Hispanics and multiracials were $11 \%$ and $8 \%$ percent, respectively. Conversely, $6 \%$ of Blacks would be displeased with results showing a single ancestral lineage from Africa. This result is hard to explain; it could be an intense commitment to multiracialism, or it could simply indicate confusion or lack of close attention to the question. 
${ }^{30}$ Whites, Hispanics, and Asians expected essentially the same reaction in other groups as in themselves, while multiracials resembled Blacks in expecting others to dislike plural results more than they themselves would.

${ }^{31}$ Agreement in the other groups was $42.5 \%$ for Hispanics, $37 \%$ for Asian Americans, and $29.5 \%$ for multiracials.

${ }^{32}$ Again the other groups were arrayed in between: $40.5 \%$ of Hispanics, $36 \%$ of Asian Americans, and $33 \%$ of multiracials stated that a DNA test showing multiple ancestral groups would affect them a lot.

${ }^{33}$ No one identifying as Asian American or Native American was profiled in the depth needed for coding.

${ }^{34}$ We re- examined the 717 articles focusing this time on mentions, not persons, as the unit of analysis, in order to identify even more clearly what the public is reading rather than what the testers are saying. Individuals were depicted in 211

newspaper stories. Coding results were very similar to those reported in the text. All of the top repeats were Black. Henry Louis Gates Jr. was named in eleven articles, the author Pearl Duncan in nine, Oprah Winfrey in five, and geneticist Rick Kittles in four.

${ }^{35}$ Alondra Nelson's (2008) research is especially illuminating on the issue process of "affiliative self-fashioning" that often results from the information provided by a DNA ancestry test.

${ }^{36}$ See also Duana(Fullwiley 2007).

${ }^{37}$ See also Tony (Frudakis 2008) and Charmaine (Royal and Dunston 2004). Gates is, of course, aware of the pernicious uses of links between biology and race; he adds that "while 'race' is socially constructed, alleles or genetic mutations are not. Biology matters. The challenge for us is to understand how it does and does not matter, especially in a society that has historically called upon 'science' to justify an oppressive social order" (Gates, Jr. 2013, p. _).

${ }^{38}$ There were too few articles from 1969-1987 (between zero and twenty a year) for the automated content analysis program to estimate proportions in each category. At the other end of the time period, Lexis Nexis does not keep records of additions or deletions to its database of U.S. newspapers. Since Lexis Nexis staff told us that such changes are frequent, we opted for consistency and therefore present results from the data that were collected in a single sitting, stopping on December 31, 2009.

${ }^{39}$ We chose names for the vignette subjects from the list of newborn names in New York City in the mid-2000s that were most common across all four racial or ethnic groups. 